
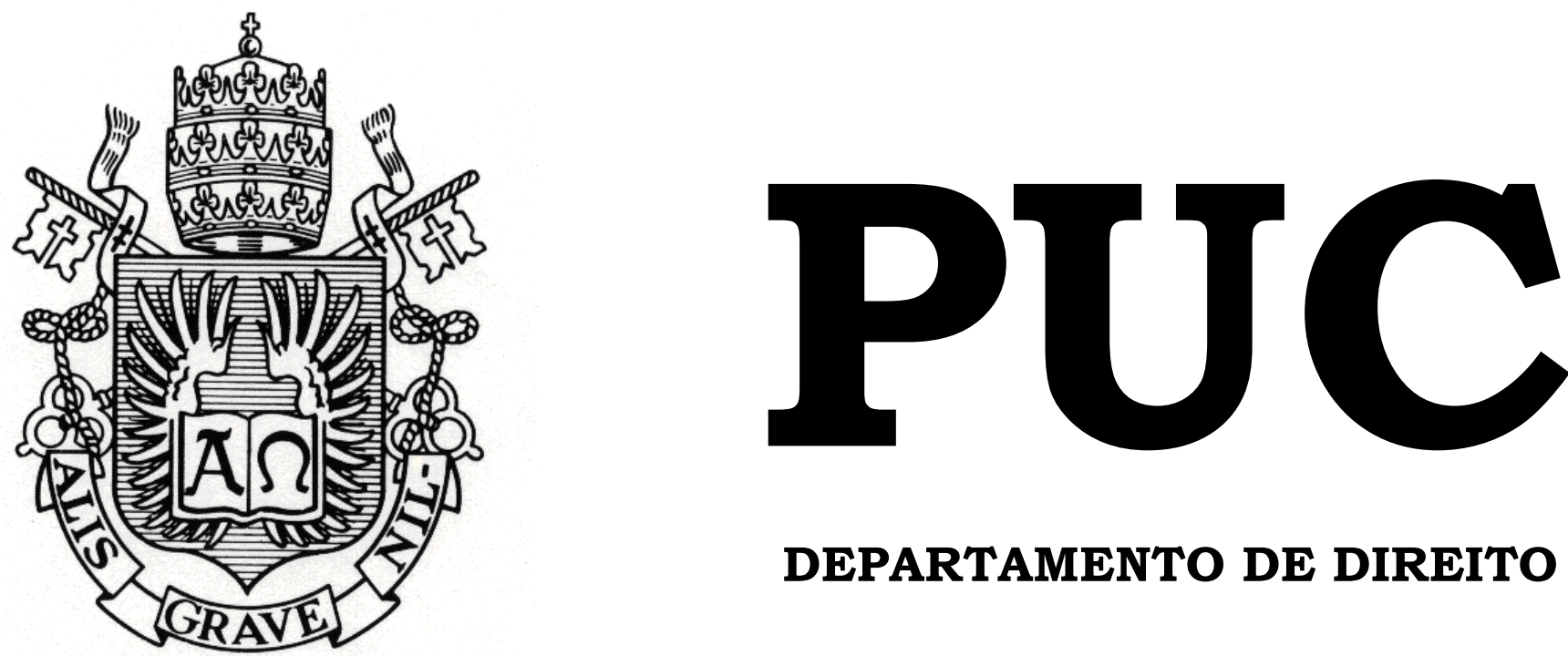

DEPARTAMENTO DE DIREITO

\title{
A Atuação da ANCINE nas Cinebiografias, a Autorização de Uso de Imagem e seus Impactos na Liberdade de Expressão.
}

por

João Marcelo Baptista Villela

ORIENTADOR: Fábio Carvalho Leite 2014.1

RUA MARQUÊS DE SÃO VICENTE, 225 - CEP 22453-900 


\title{
A Atuação da ANCINE nas Cinebiografias, a Autorização de Uso de Imagem e seus Impactos na Liberdade de Expressão.
} por

\author{
João Marcelo Baptista Villela
}

Monografia

apresentada

ao

Departamento de Direito da Pontificia Universidade Católica do Rio de Janeiro (PUC-Rio) para a obtenção do Título de Bacharel em Direito.

Orientador: Fábio Carvalho Leite 
Aos meus pais, Fernando e Marta, por todo carinho empenhado e limites impostos.

À eterna Contra Corrente por cada desafio que me presenteou. 


\section{AGRADECIMENTOS}

À equipe do escritório Senna \& Mariano Advogados Associados pelo apoio ao longo desta empreitada.

A Raquel Leiko pela atenção e boa vontade.

Ao Professor Fábio Carvalho Leite, meu orientador, pela paciência e auxílio oferecidos. 


\section{Resumo}

Este trabalho pretende explorar as particularidades que o conflito entre os direitos de imagem e a liberdade de expressão assumem em relação às Cinebiografias. Analisa, também a atuação da Agência Nacional do Cinema a partir da exigência da autorização de uso de imagem e seus impactos na produção das cinebiografias brasileiras elaboradas por produtoras independentes.

Para tanto, são discutidos aspectos dogmáticos dos direitos da liberdade de expressão e dos direitos da personalidade, bem como a cadeia de direitos atrelados às biografias em geral e àqueles exclusivamente ligados a sua versão cinematográfica.

Palavras Chave: Biografia, Direito de Imagem, Liberdade de Expressão, Direitos da Personalidade, Censura, Cinebiografia, Agência Nacional do Cinema, Lei do Audiovisual, Fundo Setorial Audiovisual. 


\section{Sumário}

Introdução.

1. Panorama Geral dos Direitos à Liberdade de Expressão e Comunicação e dos Direitos da Personalidade.

1.1. Aspectos Teóricos Relevantes à Liberdade de Expressão ao

Confronto com os Direitos da Personalidade.

1.2. A Liberdade de Expressão no Ordenamento Jurídico Brasileiro....

1.3. Aspectos Teóricos Relevantes aos Direitos da Personalidade ao Confronto com a Liberdade de Expressão.

1.4. Os Direitos da Personalidade no Ordenamento Jurídico Brasileiro

1.5. O Confronto Entre Liberdade de Expressão e Comunicação e Direitos da Personalidade - A visão patrimonialista dos direitos da personalidade.

1.6. Confronto Entre Liberdade de Expressão e Comunicação e

Direitos da Personalidade - O Princípio da Proporcionalidade.

2. (Cine) Biografias e Direito de Imagem.

2.1. As Implicações Jurídicas da Biografia como Gênero Literário e

Cinematográfico

2.2. A Noção de Imagem.

2.3. A Imagem como Bem Jurídico e o seu Conteúdo......................... 34

2.3.1. A Imagem e o Direito à Honra.................................................... 34

2.3.2. A Imagem e o Direito à Intimidade............................................ 35

2.3.3. A Imagem e o Direito à Identidade............................................ 37

2.3.4. A Imagem e a sua Autonomia.................................................... 37

2.3.5. A Imagem como Direito da Personalidade................................. 39

2.4. Características do Direito de Imagem.......................................... 40

2.5. A Proteção Constitucional do Direito à Própria Imagem............... 42

2.5.1. A Proteção Constitucional do Direito à Imagem-Retrato........... 43

2.5.2. A Proteção Constitucional do Direito à Imagem-Atributo.......... 44

2.6. O Conflito do Direito à Própria Imagem e da Liberdade de 46

Expressão e Comunicação.

3. A Atuação da ANCINE no Mercado das (Cine)biografias.......... 50

3.1. A Estrutura do Fundo Setorial Audiovisual (FSA) e a exigência de autorização de uso de imagem.

3.2. A Estrutura da Lei do Audiovisual: a exigência de autorização do uso de imagem e seu impacto nas Cinebiografias. 


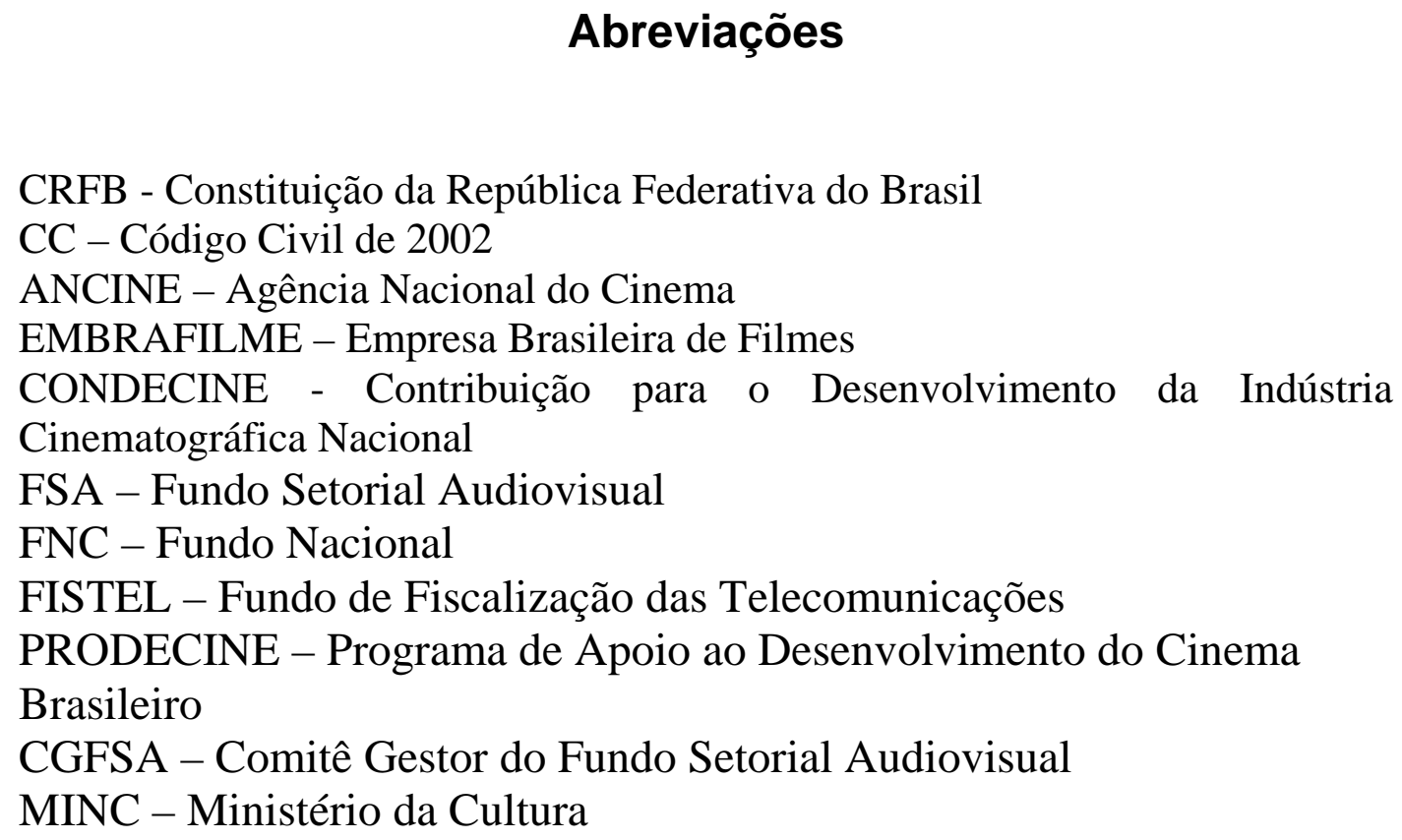




\section{Introdução}

As biografias constituem aspecto fundamental a história de um povo. É através delas que se pode entender diversos episódios históricos sob o prisma de seus protagonistas, gerando um melhor entendimento dos acontecimentos. Em sua modalidade cinematográfica, as (cine)biografias tem o condão de atingir um público significativamente mais abrangente que suas versões editoriais. Isto se dá em função da maior alcance e dinamismo que as mídias audiovisuais possuem.

Todavia, biografias de toda sorte têm sido centro constante de verdadeiras guerras judiciais no Brasil. A discussão gira em torno da exigência prescrita no artigo 20 do Código Civil, que determina como obrigatória a autorização do uso de imagem e de outros direitos da personalidade para produção de biografia o que, caso não respeitada, autoriza a retirada de circulação da referida publicação.

Isto gera um cenário aonde somente pode se publicar a respeito de alguém caso agrade ou não a si ou seus herdeiros. Desta forma, o caráter informativo das biografias pode sofrer distorções graves através da instantânea submissão do direito à liberdade de expressão e informação aos direitos da personalidade do biografado. Por consequência encontra-se o risco da mera produção de biografias “Chapa Branca”, isto é, aquelas que agradam ao biografado sem compromisso total com a verdade fática. Neste sentido, as biografias encontram-se ainda submissas à noção patrimonial do direito de imagem que tem por característica gerar lucro ao seu titular.

O que acaba por tutelado não são direitos da personalidade frente a uma informação inadequada erroneamente emitida ou um eventual abuso de direito ofensivo, mas uma proteção exacerbada dos direitos da personalidade frente a qualquer conteúdo não autorizado. Ou seja, não importa que o uso não autorizado tenha apenas narrado fatos sem a utilização indevida de qualquer informação no intuito de ofender o biografado. 
No mercado audiovisual as cinebiografias enfrentam ainda problemas de natureza distinta das suas congêneres editoriais: a cadeia produtiva de uma cinebiografia requer investimentos significativamente maiores em função da extensão da equipe trabalhando em sua elaboração. Os custos atinentes à produção de uma (cine)biografia gera para o produtor independente brasileiro a necessidade de se valer de leis de incentivo à produção audiovisual para obter a verba para esta produção.

A ANCINE (Agência Nacional do Cinema), autarquia responsável pela regulação do mercado cinematográfico, elabora os meios pelos quais o ingresso dos produtores das obras nas políticas de incentivos se dará. Todavia a autarquia, para autorizar o uso de verba incentivada, exige por diversos meios a autorização do uso de imagem quando o filme se baseia na personalidade de algum indivíduo, exigência esta embasada pelo artigo 20 do código civil.

Tal decisão reduz em muito as possibilidades da produção de cinebiografias pelos produtores independentes, principais beneficiários e interessados na legislação de incentivo à produção audiovisual. Neste sentido, monta-se um painel onde apenas grandes produtoras conseguiriam elaborar uma cinebiografia, minando aspectos fundamentais à Liberdade de Expressão e Comunicação, isto é, a própria pluralidade de visões acerca de um tema em determinado.

Vale ressaltar que as produtoras com poderio econômico suficiente para produzir uma biografia sem qualquer apoio das leis de incentivo estão atreladas a grandes conglomerados econômicos dos meios de comunicação, já tendo suficiente espaço, independente do meio cinematográfico, para divulgar sua visão a respeito de outrem.

O presente trabalho pretende, portanto, analisar os desdobramentos da atuação da ANCINE através da exigência de autorizações de uso de imagem nas cinebiografias, inseridas dentro do escopo dos mecanismos de incentivo ao mercado cinematográfico. Desta forma pretende examinar seus 
impactos na liberdade de expressão e na ideia de uma construção de memória sócio-histórica.

Para tanto, pretende, no primeiro capítulo, traçar um panorama geral dos direitos da personalidade e da liberdade de expressão apontando determinados aspectos teóricos que se fazem relevantes ao debate do tema bem como o posicionamento destes direitos no ordenamento jurídico brasileiro. Tal panorama é fundamental para a compreensão do debate a respeito das limitações que as biografias de toda sorte enfrentam no Brasil.

O segundo capítulo almeja delimitar pontos em que os aspectos das cinebiografias se afastam de suas congêneres editoriais devendo, portanto, ser analisadas de maneira apartada. Discute aspectos teóricos do direito de imagem e suas diferentes acepções para que, no caso das cinebiografias, possa se entender o que está em questão ao necessitar de uma autorização de uso de imagem.

Por fim, o terceiro e último capítulo pretende explicar como funcionam os principais mecanismos de incentivo e sua relevância no mercado audiovisual e, consequentemente, as implicações decorrentes da atuação da ANCINE frente às exigências de liberação de uso de imagem. Desta forma, visa-se demonstrar o excesso de zelo relacionado aos direitos de imagem e da personalidade frente à liberdade de expressão (que abrange tanto forma quanto conteúdo) e à liberdade de comunicação. 


\section{Panorama Geral dos Direitos à Liberdade de Expressão e Comunicação e dos Direitos da Personalidade.}

Para que uma análise adequada do tema seja feita de modo preciso, é necessário traçar um panorama geral da tutela dos institutos jurídicos da liberdade de expressão e comunicação e dos direitos da personalidade. Este capítulo pretende desdobrar seu histórico e os entendimentos presentes no direito positivo possibilitando uma análise do caso concreto sob este prisma.

\subsection{Aspectos Teóricos Relevantes à Liberdade de Expressão ao Confronto com os Direitos da Personalidade.}

"Posso não concordar com nenhuma das palavras que você disser, mas defenderei até a morte o direito de você dizê-las”. A célebre frase atribuída erroneamente a Voltaire aponta para um dos principais aspectos da Liberdade de Expressão. Tendo sido proclamada como direito subjetivo pelo Estado Liberal inspirado nos valores iluministas, a liberdade de expressão em sentido estrito pode ser considerada o direito do indivíduo de se exprimir e manifestar pensamentos, ideias, opiniões, crenças e juízos de valor de acordo com suas convicções pessoais do modo que for julgado oportuno $^{1}$. Neste sentido, é o principal instrumento de defesa das crenças de um indivíduo ou determinado grupo frente às imposições do Estado ou de outros indivíduos.

É impensável a consolidação do modelo liberal frente ao Antigo Regime sem a consagração da defesa da liberdade de expressão. Nesta ótica encontramos a Declaração dos Direitos do Homem e do Cidadão

\footnotetext{
${ }^{1}$ A noção de Freedom Of Speech consagrada na doutrina estadunidense se refere também a liberdade de meio, lugar e oportunidade na qual o discurso será proferido conferindo uma noção mais ampla de Liberdade de Expressão.
} 
proclamada ne França em 1789 e ainda a Primeira Emenda à Constituição dos Estados Unidos transcrita abaixo²:

“O congresso não legislará para e estabelecer uma religião, ou proibir o seu livre exercício; ou cercear a liberdade de expressão, ou da imprensa; ou sobre o direito do povo de se reunirem pacificamente, e de peticionarem ao governo para que sejam feitas reparações por ofensas".

A liberdade de expressão encontra enorme respaldo entre os estudiosos do direito, política e outras ciências humanas. Tal prestígio pode se considerar desdobramento da capacidade subjetiva desta garantia individual de assegurar a proteção da pessoa humana e o livre desenvolvimento da sua personalidade. Por outro lado, em uma acepção objetiva desta garantia, forma uma casca de proteção ao ideal de democracia, permitindo a participação do cidadão no debate político pluralista próprio do ambiente democrático.

Pretende, ainda, assegurar o exercício da autonomia, isto é, a reflexão do individuo a fim de decidir o sobre sua própria condição que é melhor para si e perseguir este determinado fim. Esta mesma autonomia pode ser considerada a maior expressão da realização da personalidade do indivíduo e, na medida do possível, deve permanecer imaculada.

Retomando o aspecto objetivo da liberdade de expressão, garante-se discussões mais informadas e decisões melhor fundamentadas de modo mais benéfico a todos os cidadãos. Trata-se de desenvolver uma consciência cívica elaborada a partir da livre circulação de informações que se desenvolvem a partir dos múltiplos pontos de vista existentes. Garante, ainda, voz aos descontentes face às políticas públicas, seus agentes e instituições estabelecidas.

Resta claro desta análise primária que não se deve encarar isoladamente a liberdade de expressão. Uma leitura adequada do instituto deve partir da

\footnotetext{
${ }^{2}$ Texto em tradução livre retirada do domínio http://www.law.cornell.edu/constitution/first_amendment acesso 15 Nov./2013.
} 
perspectiva da liberdade de consciência associada à liberdade democrática. Trata-se de um sistema móvel que não subsiste sem um ou outro aspecto. Para que se possa conferir uma proteção efetiva a estes dois aspectos, podese desdobrar este fim em dois princípios: o princípio da incensurabilidade e o princípio do pluralismo.

O primeiro pretende impedir qualquer restrição arbitrária que venha a se abater sobre o discurso em questão. Inadmite-se, portanto, a censura prévia ou posterior, seja ela pública ou privada. Remete expressamente à ideia de uma liberdade negativa que exige a não intervenção do Estado para a livre difusão de ideias. Em paralelo a esta não intervenção, há que se falar numa ação positiva do Estado para afastar qualquer abuso contrário à livre comunicação. Vale ressaltar que não se trata de uma imunidade absoluta da liberdade de expressão e, neste esteio, não se opõe a restrições necessárias para evitar eventuais abusos de direito.

Já o princípio do pluralismo visa à preservação do espaço dos diversos pontos de vista o quanto existam. O objetivo é dar a cada opinião espaço em prol do fortalecimento de uma cultura democrática através do tratamento equitativo das diferentes opiniões que existam acerca de uma determinada discussão, evitando a homogenia das informações e consequente redução de sua qualidade.

A liberdade de expressão encontra-se intimamente conectada ao preceito de liberdade de comunicação de modo que se mantêm imiscuídos na maior parte. A linha tênue que os separa se daria por conta da subjetividade do relato em questão. Isto é, relatos subjetivos e eivados de uma expressa impressão pessoal acerca do fato narrado, bem como opiniões e pontos de vista, constituiriam objeto da liberdade de expressão enquanto a narração do fato pura e simples constituiria objeto da liberdade de comunicação. É visível a conexão existente entre estes elementos que, no caso prático, se manifestarão de forma interligada pois o emitente da comunicação ao fazêla emite também um determinado juízo de valor crítico. Porém, não há que se polemizar o debate; tendo em vista que o caso prático permite, em regra, 
verificar o aspecto predominante quando fatos e opiniões figuram reunidos quer sejam eles objetivos ou subjetivos. Esta distinção garante de um lado o controle de abusos de direito por parte do emitente da informação/opinião, feita de modo excuso e malicioso, e por outro lado, assegura a livre circulação das notícias divulgadas de modo diligente.

\subsection{A Liberdade de Expressão no Ordenamento Jurídico Brasileiro}

A Constituição Brasileira em seu artigo 5o, inciso IV, dispõe que "é livre a liberdade de expressão, sendo vedado o anonimato.” É visível a ampla proteção oferecida pelo dispositivo em tela. Embora a norma não venha a constituir novidade na história constitucional do país, tendo a garantia se figurado repetidamente nas diversas constituições do país ${ }^{3}$, representa verdadeira vitória sobre o passado autoritário recente trazido pela ditadura militar onde cidadãos eram criminalizados por suas opiniões através de odiosas ferramentas de patrulhamento ideológico.

O instituto deixa expresso que se trata de liberdade de trazer além do foro íntimo um determinado pensamento. O direito não está interessado nos pensamentos não expressos restritos ao interior de cada indivíduo; o objeto dele é exatamente a exteriorização deste pensamento ao mundo. Ao impedir que o cidadão possa manifestar suas impressões acerca do mundo, impedese indiretamente a própria capacidade de pensar, uma vez que a mesma decorre da troca de análises subjetivas sobre a realidade que as cerca porque de nada vai adiantar o pensamento sem que se possa exprimi-lo.

Interessante destacar, este dispositivo não tem por objeto simplesmente o direito de se expressar, mas também a liberdade negativa de não expressar sua esfera íntima quando assim lhe convier. Trata-se de direito ao silêncio a

\footnotetext{
${ }^{3}$ A Constituição de 1824 fazia referência a liberdade de expressão no artigo 179, IV: Todos podem communicar os seus pensamentos, por palavras, escriptos, e publical-os pela Imprensa, sem dependencia de censura; com tanto que hajam de responder pelos abusos, que commetterem no exercicio deste Direito, nos casos, e pela fórma, que a Lei determinar.
} 
faculdade de manter em segredo suas conviç̧ões subjetivas sobre determinado tema sem que isso gere uma sanção pela postura escolhida.

A vedação ao anonimato, embora tratada em um dispositivo voltado à liberdade de manifestação do pensamento é por consequência lógica aplicável à liberdade de informação que trataremos a seguir. Por fim, se dá também em função da associação entre a ocultação de identidade do emissor, que opta por esconder sua identidade com o intuito de se esquivar das sanções consequente de sua manifestação. É um meio de evitar que os autores de mensagens apócrifas fiquem sem a sanção adequada aos danos gerados a direitos da personalidade. Por fim, vale ressaltar que a vedação ao anonimato não mira o uso de pseudônimos, isto é, o usuário do pseudônimo deve manter registrada sua identidade em um livro próprio do órgão de comunicação social que atua para que possa ser intimado caso necessário.

Em sentido mais restrito, a CRFB prevê a proteção a liberdade de expressão artística e científica no artigo 5o, inciso IX com o seguinte texto:

"é livre a expressão da atividade intelectual, artística, científica e de comunicação, independentemente de censura ou licença."

Isto significa um amparo às criações de espírito e frutos de pesquisas desenvolvidas. A liberdade destas criações corresponde ao estímulo do desenvolvimento científico-cultural fundamentais à boa educação e ao progresso, recebendo desta forma uma tutela mais apurada na ordem constitucional vigente.

Neste contexto, faz-se referência direta à liberdade de cátedra, liberdade de pesquisa e de divulgação devidamente oposta à liberdade de aprender. E novamente, retorna-se ao pluralismo como princípio de salvaguarda à liberdade de expressão nas instituições de ensino brasileiras quer sejam públicas ou privadas, vide os incisos II e III do artigo 206 da Constituição.

Ainda, no artigo 5o, inciso IX, reforça-se a ideia de afastamento da censura, pois por óbvio tratar-se-ia de uma contradição interna que acabaria por inutilizar tal liberdade. Cabe, porém, aprofundar o significado desta 
censura como o meio pelo qual os órgãos públicos visam exercer controle sobre o exercício da liberdade de expressão, destacando-se que qualquer óbice à circulação destas ideias pode ser considerada censura, independentemente da entidade responsável por exercer o controle. Não são raras as vezes em que entes privados se valem do poderio econômico com o objetivo de impedir a circulação de um determinada ideia. Tal receio pode se confirmar, no que concerne ao tema, na força que os grandes grupos de comunicação exercem sobre o Brasil.

O artigo oferece ainda resguardo à liberdade de informação. Ressalte-se, como dito antes, que se trata de comunicação objetiva de fatos tais como notícias. Diz respeito à comunicação pública feita a um grupo de pessoas, não àquelas de caráter pessoal e sigiloso. Entende-se assim, como liberdade de comunicação àquela feita visando a ampla difusão de notícias.

Embora o poder constituinte não tenha estabelecido como pré requisito para a circulação de uma determinada informação sua veracidade, é cristalino o entendimento de que não há tutela constitucional à informação falsa. A própria proteção à liberdade de comunicação pressupõe que os fatos difundidos sejam verídicos. Caso se tutele a informação falsa, restará prejudicado o próprio telos da liberdade de expressão e comunicação como um todo porque a própria noção do debate democrático e troca de informações fundamentadas restará prejudicado, isto é, o direito de ser informado. Vale ressaltar que a verdade da informação se erige da diligência das fontes desta informação antes de sua divulgação ao público num esforço de evitar qualquer assimetria.

Como um direito conexo, a Constituição proclama ainda o direito ao acesso à informação no artigo 5o, XIV:

"é assegurado a todos o acesso à informação e resguardado o sigilo da fonte, quando necessário ao exercício profissional.”

Este direito diz respeito a todos os cidadãos, porém quanto ao sigilo das fontes é algo particularmente importante para os comunicadores e 
produtores de conteúdo comunicacional. Ou seja, embora não exclusivo, é essencialmente ligado ao bom desempenho do papel de comunicador.

Conforme mencionado anteriormente, o anonimato também é vedado à emissão da informação pelos mesmos motivos aplicáveis à emissão de um determinado pensamento. Não há que se falar em antinomia com o sigilo que preserva as fontes. Este se destina a manter a fonte anônima para sua preservação, não a manter o anonimato do responsável pela emissão da notícia.

Quanto ao sujeito passivo do direito de comunicação, isto é, o consumidor da informação, não há que se falar em um direito moral, mas um direito legitimamente tutelado de receber a informação, inclusive deve ser enxergado como o próprio fim em si do direito de comunicação. Não há que se falar em emitir uma comunicação sem um interlocutor que a receba.

Ressalte-se novamente a importância da pluralidade para a liberdade de comunicação, isto é, a obtenção das notícias e informações através de fontes variadas em si. Tal direito retoma, mais uma vez, a noção de soberania e democracia bem como a escolha melhor fundamentada quanto as decisões socialmente relevantes e que implicam na soberania da nação.

\subsection{Aspectos Teóricos Relevantes aos Direitos da Personalidade ao Confronto com a Liberdade de Expressão.}

Direitos da personalidade podem ser definidos como aqueles inerentes à pessoa e à sua própria dignidade; trata-se da tutelar a plena realização da personalidade, ou seja, assegurar um espaço mínimo com o intuito de que cada um possua autonomia o suficiente para perseguir seus objetivos de vida que lhe satisfaçam sem a interferência de terceiros nas suas escolhas.

Em termos historiográficos, a acepção dada à pessoa humana enquanto valor intrínseco em si e, portanto digna de proteção, é recente. Entretanto, podemos traçar um caminho percorrido até a tutela atualmente oferecida 
aos direitos decorrentes da própria condição de pessoa humana ${ }^{4}$. Trata-se de avaliar uma mudança do sistema de proteção da pessoa - tendo em vista que o centro desta proteção adivinha dos primeiros códigos civis. E, neste cenário, podemos destacar duas causas para a mudança da situação jurídica da pessoa humana: o cristianismo e as declarações de direitos decorrentes do século XVIII 5 .

Apesar de todo reacionarismo cristão durante a idade média visando à manutenção de um mundo teocêntrico para a manutenção de seu status quo, ao destacar o livre arbítrio do individuo frente à sociedade, ressalta a questão da escolha individual. A declaração de direitos do século XVIII apontam para o rompimento dos grilhões que amarravam o homem às limitações impostas pelo feudalismo. Surge assim um novo cenário politico-cultural apontando para o Estado de Direito onde o individuo se torna sujeito ativo de diversas prerrogativas.

Tratava-se de firmar a posição individual da pessoa frente ao Estado decorrendo daí uma noção individualista do direito. Estes direitos servem, portanto, ao estabelecimento e manutenção da nova ordem econômica que se ergue - a liberdade garantida implica a liberdade econômica e o modo como seria exercido seria o principal papel dos códigos civis vigentes à época. O objetivo era a restruturação de um modelo sócio econômico a partir das relações interpessoais.

Neste esteio, o século XIX trouxe à tona a dicotomia direito público/direito privado negando uma leitura de uma sistemática jurídica fundada em valores constitucionais, assim, as constituições encerravam limitações à atuação dos Estados. Consequentemente, erigia-se um quadro onde afirmava-se a liberdade do individuo frente ao Estado devidamente balizada por uma igualdade formal entre os homens. Nas relações privadas não haveria uma tutela específica e individualizada por parte do

\footnotetext{
${ }^{4}$ DONEDA, Danilo. Os Direitos da Personalidade no Código Civil. In: TEPEDINO, Gustavo (Org.) A Parte Geral do Novo Código Civil. $3^{\mathrm{a}}$ ed. Rio de Janeiro: Renovar, 2007. p.36

${ }^{5}$ Ibid. p.37
} 
ordenamento jurídico, não se tratava de tutelar uma igualdade efetiva entre partes mas assegurar a autonomia privada.

$\mathrm{O}$ século XX trouxe transformações de profundo impacto na ordem sócio-política e econômica vigente até então. À medida que as relações sociais se tornavam mais elaboradas, já não havia espaço para uma tutela de direitos exclusivamente baseada na proteção da propriedade. Neste cenário o direito assume o dever de equilibrar interesses anteriormente estranhos à sua tutela, enfrentando a questão da desigualdade social existente oriunda da igualdade estritamente formal. Esta transformação paradigmática deu origem à proteção dos chamados de direitos da personalidade.

Dentre os instrumentos que apontam para esta leitura inovadora firmando os limites nítidos destes direitos pode-se citar o BGB alemão rompendo com a tradição do Code francês que, embora não faça menção direta a esta nova categoria de direitos traça o novo paradigma a ser seguido. Com a Constituição de Weimar em 1919, a mudança de prisma da proteção do direito civil pode ser considerada consolidada. Ela traz os conceitos base do direito civil tais como propriedade ou direito contratual promovendo o estreitamento existente no vão entre direito público e direito privado $^{6}$. Os direitos nela previstos deveriam se aplicar aos casos práticos sempre que estiver em questão a personalidade.

No pós-guerra a doutrina começa a enxergar nos direitos da personalidade seu caráter atual. A doutrina pontua nestes direitos um limite mínimo necessário para a existência e a criação de condições adequadas ao desenvolvimento pessoal. Trata-se de uma visão comunitária do desenvolvimento pessoal adequado ao indivíduo, não enxergando meramente a defesa de um polo de interesses, seja ele indivíduo-indivíduo ou indivíduo-Estado; é uma construção diretamente voltada à solidariedade como valor para a plena realização de cada personalidade.

O desafio doutrinário enfrentado passa a ser posicionar este novo rol de direitos no direito civil estruturado a partir da noção liberal-burguesa, onde

\footnotetext{
${ }^{6}$ Ibid. p.40
} 
seu ponto de referência era a propriedade. Neste sentido, o direito se estabelece como mediador de interesses em situações que anteriormente seriam solucionadas em outras instâncias tais como família ou a igreja, enfrentando, consequentemente, a questão da desigualdade social7

O próprio meio de tutela se torna uma questão relevante ao direito civil, tendo em vista que o bem jurídico, nas novas hipóteses, se confundiria com o seu titular, não cabendo assim técnicas de proteção adequadas aos direitos subjetivos $^{8}$; a discussão gerou em torno de tipificar propriamente estes direitos. A solução encontrada para esta questão se deu através da tutela de uma regra geral referente a qualquer situação prática nas quais os bens relativos à personalidade estivessem em questão, tendo assim, ocorrido o reconhecimento do direito geral da personalidade ${ }^{9}$.

Não se trata de adequar os direitos da personalidade no âmbito de proteção oferecido ao direito subjetivo oriundo da noção patrimonialista desta segunda espécie. Tendo em vista que a referida discussão não se encontra totalmente superada e não é particularmente necessária ao debate que se pretende desenvolver tomaremos os direitos da personalidade como honra, imagem, privacidade e intimidade que encontram consenso na doutrina quanto à sua condição jurídica.

\subsection{Os Direitos da Personalidade no Ordenamento Jurídico Brasileiro.}

O Código Civil de 2002 trouxe a celebrada mudança através da inclusão de um capítulo próprio quanto à proteção da personalidade jurídica compreendido entre os artigos 11 a 21, embora não se trate de exata novidade, uma vez que a Constituição prevê uma série de normas que tratam exatamente da proteção à personalidade. Para a presente discussão cabe ressaltar o que o professor Gustavo Tepedino chama de cláusula geral

\footnotetext{
${ }^{7}$ Ibid. p.40

${ }^{8}$ Ibid. p.42

${ }^{9}$ Ibid. p.44
} 
de tutela da personalidade ${ }^{10}$ isto é, o conjunto de normas constitucionais formadas pela consideração da cidadania e da dignidade da pessoa humana como fundamento da República (artigo 1o, II e III da CRFB), as garantias de igualdade material pressuposto pela erradicação da pobreza e da redução das desigualdades sociais e regionais (artigo 3o, III, da constituição) e a igualdade formal. A tutela originária da pessoa decorre direto da constituição, devendo a legislação subordinada a Constituição estar de pleno acordo com a Lei Maior e cabendo uma interpretação civilconstitucional da matéria.

Esta cláusula pode ser tomada como o alicerce de solução de qualquer caso que se imponha violação a determinado direito da personalidade. A solução adequada deve se dar a partir da priorização da pessoa como valor. A proteção da pessoa não deve ser feita de modo divisível em função de cada hipótese em particular; a análise em separado das particularidades do caso prático é que permitem a tutela específica da personalidade, entretanto os paradigmas de proteção da personalidade encontram-se fixados na cláusula geral de tutela da personalidade.

O legislador infra-constitucional em acertada decisão, ao incorporar formalmente os direitos da personalidade ao código civil, optou por não pretender esgotar estes direitos em seu texto tendo, portanto, legislado sobre temas já consolidados à cerca dos direitos da personalidade. Assim, deixa espaço livre para a evolução da discussão em sede jurisprudencial própria ao dinamismo do direito contemporâneo. Aprofundaremos apenas as discussões referentes aos direitos da personalidade com implicação direta nas (cine)biografias a serem discutidas mais à frente no presente trabalho.

Os artigos 20 e 21 do código civil de 2002 dispõe o seguinte:

Art. 20. Salvo se autorizadas, ou se necessárias à administração da justiça ou à manutenção da ordem pública, a divulgação de escritos, a transmissão da palavra, ou a publicação, a exposição ou a utilização da imagem de uma pessoa poderão ser proibidas, a seu requerimento e sem prejuízo da indenização que couber, se lhe

\footnotetext{
10 TEPEDINO, Gustavo. A tutela da personalidade no ordenamento civil-constitucional brasileiro. In: TEPEDINO, Gustavo. Temas De Direito Civil. $3^{\mathrm{a}}$ ed. Rio de Janeiro: Renovar, 2004. p.47
} 
atingirem a honra, a boa fama ou a respeitabilidade, ou se se destinarem a fins comerciais.

Parágrafo único. Em se tratando de morto ou de ausente, são partes legítimas para requerer essa proteção o cônjuge, os ascendentes ou os descendentes.

Art. 21. A vida privada da pessoa natural é inviolável, e o juiz, a requerimento do interessado, adotará as providências necessárias para impedir ou fazer cessar ato contrário a esta norma.

O legislador foi infeliz ao redigir o artigo 20 pois, embora vise tratar diretamente do direito à imagem, mitiga o direito à liberdade de expressão e informação de maneira desproporcional. Ao apresentar mecanismos para que um determinado indivíduo possa impedir a divulgação de determinado aspecto de sua imagem pessoal, cria um meio célere de ceifar a circulação da informação sem qualquer discussão mais aprofundada acerca do tema. A proteção da privacidade oferecida pelo artigo 21 do código civil representa, em conjunto com o artigo supra citado, outro meio ágil para impedir qualquer exposição minimamente incômoda.

Tendo em vista que a constituição consagra a proteção à intimidade (artigo 5o, X) e também a proteção às liberdades de expressão e informação (artigo 5o, IX) sem nenhuma hierarquia normativa entre elas, a postura do legislador infraconstitucional foi equivocada ao conceder uma faculdade tão extensa ao particular para poder retirar conteúdo a seu respeito que o desagrade de circulação, oferecendo, inclusive, uma suposta solução absoluta a qualquer situação fática.

Cabe ressaltar, ambos artigos do código civil ignoram o fato da responsabilidade civil se erigir como via adequada a sanar eventuais danos e condutas anti-jurídicas. O dano não patrimonial também chamado de dano moral está estreitamente conectado à violação de um interesse não quantificável, ou seja, lesão a direito da personalidade. Consistem em dano a bens da personalidade, tais como a honra, a liberdade, a saúde, a integridade psicológica, causando dor, sofrimento, tristeza, vexame e humilhação a vítima, e ainda os novos direitos da personalidade: intimidade, imagem, bom nome, privacidade, a integridade da esfera íntima. 
Há que se destacar os critérios intrínsecos da teoria do dano que são ignorados pelos artigos 20 e 21. Para que o ato ilícito seja caracterizado como tanto deve-se levar em conta a) a voluntariedade do dando; b) a ocorrência do dano e c) a relação de causalidade entre o ato e dano perpetrado. Desta forma, o próprio direito civil apresenta uma saída a reparação dos danos morais gerados por eventual violação da privacidade do indivíduo não havendo razão para a dependência de uma censura prévia nos termos dos artigos 186 e 187 do código civil:

Art. 186. Aquele que, por ação ou omissão voluntária, negligência ou imprudência, violar direito e causar dano a outrem, ainda que exclusivamente moral, comete ato ilícito.

Art. 187. Também comete ato ilícito o titular de um direito que, ao exercê-lo, excede manifestamente os limites impostos pelo seu fim econômico ou social, pela boa-fé ou pelos bons costumes.

Assim sendo o óbice à circulação de opiniões/informações postulado nos artigos 20 e 21 do código civil constituem verdadeira censura privada à liberdade de expressão e comunicação. A própria jurisprudência atua de modo draconiano no sentido de impedir qualquer circulação destes bens jurídicos quando eventualmente indesejados pelo seu "legítimo” titular.

\subsection{O Confronto Entre Liberdade de Expressão e Comunicação e Direitos da Personalidade - A visão patrimonialista dos direitos da personalidade}

Feita a prévia análise jurídico-histórica destas instituições, passemos à análise da situação fática resultante da discussão da constitucionalidade dos artigos 20, na qual os dois institutos figuram contrapostos em si, ilustrando um quadro de aparente antinomia constitucional. O judiciário brasileiro atualmente enfrenta a questão na instância do Supremo Tribunal Federal que, exercendo seu papel de corte constitucional, há de julgar a Ação Direta de Inconstitucionalidade 4185 impetrada pela Associação Nacional dos Editores de Livros - ANEL visando a livre publicação de biografias. 
Passando à análise do caso: a referida ação punge por atribuir aos artigos 2021 do código civil interpretação conforme a constituição. Não se trata de afastar do ordenamento jurídico brasileiro a proteção à vida privada e a intimidade, valores consagrados no texto da Lei Maior regularmente assegurada no inciso $\mathrm{X}$ do art. $5^{\circ}$. O ponto em questão é enfrentar a proteção excessiva proporcionada pelo código civil através da amplitude semântica e abrangência protetiva ${ }^{11}$ como coloca Gustavo Binenbojm, dos dispositivos que finda por vilipendiar as liberdades de expressão e informação que restam inutilizadas.

A restrição fornecida pelos dispositivos impugnados na ADIN criam um direito potestativo (praticamente um interdito proibitório, instrumento adequado evitar esbulhos à propriedade) ao indivíduo biografado e seus herdeiros para retirar de circulação o relato trazido pela biografia. $\mathrm{Na}$ prática o que se defende é uma leitura patrimonialista aos direitos de intimidade e privacidade, tendo em vista que por diversas vezes a anuência para a referida publicação advêm do pagamento de uma determinada quantia a título de licenciamento de uso de imagem. Esta prática vai de confronto com a interpretação civil constitucionalista que se pretende dar aos direitos da personalidade assim elaborados no pós-guerra.

Retomando o que foi apresentado no tópico 1.3., trata-se de atribuir uma visão jurídica à autonomia privada típica do século XIX aonde o papel do direito civil era a mera manutenção da iniciativa econômica privada, não restando preocupada com qualquer implicação comunitária. Vale ressaltar, as noções de proteção a intimidade e privacidade têm origem no século XX, num contexto sistematizado de direitos onde não se trata de defender a autonomia privada frente a um Estado abusivo e discricionário como o do século anterior. Isto posto, o direito positivo dá uma interpretação ultrapassada a direitos criados sob uma ótica de proteção e desenvolvimento do espaço mínimo existencial visando a autonomia individual para que cada pessoa possa buscar a plena realização de sua personalidade.

${ }^{11}$ Petição inicial da ADIN 4185 
Note-se o seguinte acórdão da $3^{\mathrm{a}}$ Turma do STJ nos autos do Recurso Especial 299832 de 21 de fevereiro de 2013:

\begin{abstract}
REsp 299832 / RJ RECURSO ESPECIAL 2001/0004159-0
RECURSO ESPECIAL. RESPONSABILIDADE CIVIL. AÇÃO DE INDENIZAÇÃO POR DANOS MORAIS E MATERIAIS. DIREITO À IMAGEM. ATLETA. UTILIZAÇÃO SEM AUTORIZAÇÃO PARA PROMOÇÃO DE EVENTO. VIOLAÇÃO DE DISPOSITIVOS CONSTITUCIONAIS. NÃO CABIMENTO. AUSÊNCIA DE FINS LUCRATIVOS. IRRELEVÂNCIA. DANO MORAL. PROVA. DESNECESSIDADE. PRECEDENTES. DOUTRINA. 1. Compete ao Superior Tribunal de Justiça, em sede de recurso especial, a análise da interpretação da legislação federal, motivo pelo qual se revela inviável invocar, nesta seara, a violação de dispositivos constitucionais, porquanto matéria afeta à competência do STF (art. 102, inciso III, da Carta Magna). 2. A obrigação da reparação pelo uso não autorizado de imagem decorre do próprio uso indevido do direito personalíssimo e não é afastada pelo caráter não lucrativo do evento ao qual a imagem é associada. 3. Para a configuração do dano moral pelo uso não autorizado de imagem não é necessária a demonstração de prejuízo, pois o dano se apresenta in re ipsa. 4. Recurso especial parcialmente conhecido e, nessa parte, parcialmente provido. (grifos do autor)
\end{abstract}

Ou seja, queda cristalizado o entendimento de que a imagem é algo intocável e seu simples uso não autorizado já constituiria dano moral (de contornos patrimoniais) sem sequer restar provado qualquer nexo de causalidade ou mesmo a existência de um determinado prejuízo. Assim a jurisprudência afasta como pré requisito a própria existência do dano para a configuração de uma indenização. Deste modo a aplicação do dano moral in re ipsa, isto é, decorrente da força do próprio fato, encontra-se aplicado de modo banal em circunstância aonde a existência do dano é plenamente verificável.

Um exemplo ilustrativo desta mercantilização indesejada ao bom funcionamento do sistema de proteção a pessoa humana se dá na entrevista dada a Folha de São Paulo em 2010 dada por Irami Medeiros de Rosa, sobrinha do famoso sambista Noel Rosa. Alegando invasão de privacidade por parte do biógrafo do tio, moveram subsequentes ações contra os autores da biografia do compositor alegando diferentes argumentos, sempre sob o prisma da intimidade ${ }^{12}$ :

\footnotetext{
${ }^{12}$ CARNEIRO, Luiz Felipe. - O terreno minado das biografias não autorizadas no Brasil. In: Schreiber, Anderson. Direito e Mídia. 1aㅡ ed. Rio de Janeiro: Renovar, 1999. p.126
} 
"O livro esmiúça nossa vida privada, botou minha família na lama. Isso é inveja, nao conheço os autores, mas os comentários deles não me atingem. Sem o livro, eles devem estar bem tristinhos. Confio incondicionalmente no meu genro, que cuida de tudo isso, não vou mais me envolver, já estou com uma certa idade. Mas não tenho pressa, nunca precisei de direito autoral para sobreviver. É tudo uma questão de sentar e negociar." (grifos do autor)

Resumindo, o que prioritariamente tem se buscado nesta discussão não passa por preservar a imagem de uma família ou de um ente querido morto. Trata-se de transformar a memória coletiva em produto comercial que possa ser "negociado" entre partes remontando ao preceito de negociabilidade de qualquer bem jurídico como bem de mercado promovido pela noção liberal clássica de direito privado. Neste sentido se manifesta o professor Carlos Alberto Bittar:

Essa disponibilidade permite ao titular extrair proveito econômico do uso de sua imagem, ou de seus componentes, mediante contratos próprios, firmados com os interessados, em que autorizam a prévia fixação do bem almejado(...) Constituem, assim, atos ilícitos, não só o uso consentido, como também o uso que extrapole os limites contratuais (em finalidade diversa, ou não expressamente ajustada) em qualquer situação em que seja colhida, ou fixada a pessoa, para posterior divulgação, com ou sem finalidade econômica ${ }^{13}$.

Não se faz qualquer menção a própria indisponibilidade dos direitos da personalidade também presente no código civil (artigo 11 da lei) implicando num enfraquecimento do próprio instituto da privacidade através da sua banalização. Isto posto, a interpretação a qual alguns civilistas se entregam de braços abertos de defesa da personalidade em via de censura privada se demonstra danosa ao próprio instituto jurídico. A noção patrimonialista do direito civil encontra respaldo nas teorias civilistas dos direitos da personalidade como direitos subjetivos de modo que estejam sempre contrapostos a uma obrigação de terceiros. A preocupação dada não é a malícia da informação divulgada e seu fim, mas simplesmente uma

${ }^{13}$ BITTAR, Carlos Alberto. Os direitos da personalidade. 2. ed. Rio de Janeiro: Forense Universitária, 1995. p.87-89. 
violação da propriedade de uma pessoa por um terceiro em aproveitamento econômico próprio.

O direito civil contemporâneo visa desmontar esta leitura da privacidade sob o dogma da propriedade inserindo-o sob o âmbito da proteção da pessoa. Não se trata de escancarar ao público informações pessoais sensíveis(prontuários médicos, dados bancários e quaisquer dados restritos ao público), mas deixar que manifestações da personalidade feitas de modo voluntário trazidos a vida pública tenham seu fluxo liberado sem quaisquer impedimento prévio.

Os relatos feitos de forma abusiva permanecerão como condutas antijurídicas, contudo, trata-se de não dar uma presunção absoluta de legalidade a atos controversos em franco embate com a liberdade de expressão. Todavia, ao se submeter a juízo a posteriori tem-se a possibilidade de proceder a verificação do dano (requisito intrínseco a responsabilização civil) através do próprio caso prático; não de um dano em abstrato como punge o atual entendimento judiciário. Entendimento esse que se traveste de verdadeira censura privada, cabe salientar.

\subsection{O Confronto Entre Liberdade de Expressão e Comunicação e Direitos da Personalidade - O Princípio da Proporcionalidade.}

Conforme já demonstrado previamente, a possibilidade de proibição a priori com fulcro nos artigos 20 e 21do código civil propiciam a redução do âmbito de proteção a liberdade de expressão e comunicação encerrada nos incisos IV, IX, X e XIV do artigo 50 da constituição. Em uma defesa exacerbada da privacidade e intimidade, os artigos da legislação infraconstitucional dão ensejo ao impedimento da circulação de informações essenciais à manutenção da democracia.

Em se tratando de dois princípios caros à ordem jurídica nacional, cabe uma leitura a sobre a mitigação decorrente do aparente conflito entre os mesmos. Como instrumento utilizado, passaremos a uma análise à luz do 
princípio da proporcionalidade/razoabilidade e eventual violação do mesmo. Embora não haja explícita tutela do princípio na Constituição, é pacífica sua aplicação pela jurisprudência. Esta leitura será feita a partir do desdobramento do princípio em três regras básicas: adequação, necessidade e proporcionalidade em sentido estrito.

Primeiramente, analise-se a relação entre as medidas tomadas e o fim ao qual elas se pretendem, isto é, adequação entre o meio e o fim. A lei deve perseguir um fim legítimo ao Estado; mesmo que não o fim não se atinja pela mera aplicação da medida, esta deve se prestar a aproximar e direcionar ao objetivo ao qual se pretende chegar. Assim, a inadequação da medida restará verificada quando sua aplicação não se prestar a estreitar o objetivo pretendido.

Verificada a adequação, analisa-se a necessidade da norma. Significa dizer que a restrição de um princípio em detrimento de outro deve-se mostrar necessário, não havendo via substituta adequada a este fim. Tratase de buscar o caminho menos oneroso possível para se tutelar um determinado fim com a mesma intensidade de maneira a danificar o mínimo possível o direito fundamental a ele contraposto; pressupõe-se uma comparação entre os meios de tutelas existentes.

Passa-se, por fim, a análise da proporcionalidade em sentido estrito. Verifica-se uma ponderação direta entre o ônus imposto e o benefício que se visa atingir. Nesta situação deve-se comparar o quão intensa a restrição de direito fundamental se demonstrará frente a importância do benefício trazido ao direito fundamental ora colidente. Quanto mais intensa a restrição se demonstrar, mais urgente é a tutela ao direito que se encontra em sentido oposto.

Retomando a análise da ponderação em tela e fim ao qual os artigos 20 e 21 do código civil dizem respeito à tutela dos direitos da personalidade como conjunto. O meio utilizado para resguardar estes direitos fundamentais, ora colidentes com as liberdades de expressão e 
comunicação, foi a faculdade de se retirar de circulação o conteúdo não autorizado.

A medida se mostra adequada ao fim que se pretende uma vez que a vedação à circulação não autorizada cria como parâmetro o crivo daquele que tem sua suposta privacidade exposta como pré requisito. Não há outro meio de mesma intensidade para se proteger a intimidade de uma eventual exposição maliciosa. Todavia, ao analisar-se a proporcionalidade em sentido estrito, ignorando todos os postulados pela liberdade de expressão e comunicação, resta visível o dano ao ambiente democrático. Desta forma o cerceamento é desproporcional ao fim que se pretendia atingir criando uma hierarquia entre a liberdade de expressão e em comunicação frente aos direitos da personalidade.

Não se trata de criar um cenário de absoluta liberdade à informação veiculada, porém, não há que se olvidar que nos moldes atuais há uma verdadeira postura de absoluta prevalência da intimidade frente a liberdade de expressão e comunicação. Sem qualquer juízo mais aprofundado do caso prático discutido, erige-se uma verdadeira relação de submissão da liberdade de expressão e comunicação frente aos direitos da personalidade o que tanto do ponto de vista prático quanto do aspecto dogmático é caso problemático. 


\section{2. (Cine) Biografias e Direito de Imagem.}

Neste capítulo pretende-se abordar a relação de direitos encadeada pelas biografias cinematográficas, distinguindo-as das biografias literárias, tomando como parâmetro os direitos de liberdade de expressão e comunicação, bem como os direitos da personalidade do biografado. Feita esta distinção, passarei à análise da atuação da ANCINE e a maneira como implica em uma restrição excessiva a liberdade de expressãopordiversas vezes.

\subsection{As Implicações Jurídicas da Biografia como Gênero Literário e Cinematográfico}

Pode-se definir Biografia como um gênero literário em que o autor narra a história da vida de uma ou várias pessoas. Assim, cumpre esclarecer que a biografia, por natureza, não pretende como uma narrativa absoluta. A biografia resta posicionada entre a reprodução de um fato real e o imaginário do biógrafo, que pretende recriar uma realidade perdida utilizando de preenchimentos ficcionais. O recurso a ficção é inevitável na medida em que é impraticável recriar precisamente os eventos pretéritos por ela narrada ${ }^{14}$.

Nesta relação, logicamente, a narrativa não corresponderá jamais integralmente àquela realidade narrada. A partir da acepção que todo biografado é fundamentalmente plural em suas relações privadas e detentor de vínculos distintos ${ }^{15}$, a biografia não se pretende como narrativa da História. Apesar da lógica aproximação entre ambos os gêneros, a biografia se pretende uma individualização da personalidade retratada situada em um contexto apartado da realidade objetiva. Nas palavras de François Dosse “ $O$ biógrafo precisa consagrar sua própria existência a esclarecer a vida de

\footnotetext{
${ }^{14}$ DOSSE, François - O Desafio Biográfico: Escrever uma vida. $1^{\text {a }}$ ed. São Paulo: EdUSP.2009 p. 55

${ }^{15}$ Ibid - Pg. 297
} 
um estranho" e ainda "O biógrafo sabe que jamais concluirá sua obra, não importa o número de fontes que consiga exumar."

O que a biografia permite, portanto é a reconstrução de um vivido real passado sob a ótica de um terceiro que não vivenciou os episódios narrados. Esta espécie de releitura sobre os fatos será embasada pela pesquisa de dados encadeados de modo diretamente relacionado à criatividade e talento do seu autor.

Não se trata, pois, de promover uma invasão da intimidade do biografado ou dos seus herdeiros dentro do seio familiar, visto que a narrativa terá influência notável da subjetividade do autor. Assim, por mais que se aproxime da realidade dos fatos, a biografia não deixará de lado em alguma medida o cunho estritamente historiográfico da narrativa, mesmo que faça uso da imagem-atributo do biografado e consequentemente nela exerça impactos. Tanto o biógrafo que irá elaborar a biografia editada quanto o roteirista de cinema de um determinado filme biográfico contarão uma determinada história a partir de sua impressão pessoal.

De acordo com Marcio Markenkof, doutor em literatura e professor do curso de cinema da Universidade Federal de Santa Catarina, as biografias têm o papel de organizadoras de memórias, organizações essas repetidas em produções que podem refletir valores ou mesmo induzi-los, formatando registros que deveriam ser únicos - como cada indivíduo o é - em fórmulas e caracterizações de vida. Personalidades podem ser retratadas como exemplares de suas sociedades, seus gêneros, atividades, etnias, religiões, e modos de moldar a memória do mundo ${ }^{16}$.

A Cinebiografia, pelas possibilidades presentes da mídia audiovisual, pode atingir diretamente outros signos distintivos de cada personalidade chegando a imagem-retrato e seus sinais distintivos a ela atrelados tais como trejeitos, atitude e até mesmo a voz dependendo de sua natureza.

\footnotetext{
${ }^{16}$ DELFINA, Cristiana, Generalizando a vida real. O que retratam as cinebiografias? Disponível em <http://www.comciencia.br/comciencia/handler.php?section=8\&edicao=96\&id=1177 a > Acesso 22 mai. 2014
} 
No caso do cinema, esses registros passam por diversas influências até tornarem-se quer filmes de ficção que enfeitam, adicionam e subtraem referências e narrativas que nunca fizeram parte da vida dos retratados, quer em documentários que expõem documentos e depoimentos na tentativa de disciplinar as memórias, mas que não seriam menos dependentes das subjetividades de seus criadores, todavia.

A cinebiografia, em função do seu caráter de criação coletiva, terá diversos pontos de vista conjugados ao seu fim. Isto é, trata-se da interpretação dada à história pelo roteirista, por exemplo, por parte do diretor de fotografia, da direção de arte, da direção de atores etc. Quanto maior o número de envolvidos mais mitigada restaria o resultado final e a impressão sobre o biografado. Marcio Markenkof ressalta:

“A força das cinebiografias reside, pois, nesta capacidade de tratar a vida de sujeitos de forma dramática, romanesca e condensada e, assim, transformar o espectador mais próximo do biografado do que aquela figura descrita nos livros. Com uma conexão entre os fatos mais evidente, como é a proposta da narrativa clássica do cinema, o público acaba por entregar-se muito mais às próprias emoções, uma vez que está diante de uma verdade poética. ${ }^{17}$ "

Cumpre aqui separar o escopo das cinebiografias dramatizadas, que correspondem a representações dramatológicas do seu objeto, e àquelas que lançam mão de imagens, depoimentos e relatos não dramatizados, compondo o esteio da produção de modo que muitas vezes utilizam sinais distintivos da personalidade biografada tais como voz em discursos ou a imagem strictu sensu do biografado para concluir a narrativa.

Nada mais natural, que por implicar em aspectos distintos do direito da personalidade, receba uma tutela diferente a sua congênere literária. A seguir analisaremos o direito à imagem e suas possíveis abordagens que se relacionam com os aspectos diversificados das cinebiografias.

\subsection{A Noção de Imagem}


O professor Luiz Alberto David de Araújo fala não na noção de imagem mas verdadeiramente de imagens $^{18}$. Neste sentido diferencia àquela que a tradicional doutrina civilista aponta como imagem nominando-a imagemretrato, mais genérica, em separação daquilo que chama de imagematributo. No intuito de melhor compreender ambas imagens passaremos a sua análise:

Tradicionalmente a imagem para a doutrina civilista (imagem-retrato) deve ser entendida como a representação da figura humana independente da maneira como seja feita e em consequência, a imagem é, no mínimo o aspecto físico da pessoa captado e fixado em algum suporte material ou imaterial $^{19}$. Em constante evolução tecnológica são incontáveis as formas e suportes materiais de representação e seus substratos técnicos para que se permita a exibição da pessoa, de modo que, no intuito de se obter uma efetiva tutela do direito a imagem, não há que categorizar quais meios correspondem à exibição de imagem.

Note-se, o enfoque gira em torno do aspecto visual destacado sem se levar em conta a noção mais abrangente que a imagem vem a ter. Neste sentido, Walter de Moraes afirma que “toda expressão formal e sensível da personalidade de um homem é imagem para o Direito ${ }^{20}$ ”. Ainda neste sentido acrescenta magistralmente:

\footnotetext{
"A idéia de imagens não se restinge, portanto, à representação do aspecto visual da pessoa pela arte da pintura, da escultura, do desenho, da fotografia, da configuração caricata ou decorativa , da reprodução em manequins ou máscaras. Compreende, além, a imagem como a de fotografia e da radiodifusão, e os gestos, expressões dinâmicas da personalidade. ${ }^{21}$ "
}

\footnotetext{
${ }^{17}$ DELFINA, Cristiana, Generalizando a vida real. O que retratam as cinebiografias? Disponível em <http:/www.comciencia.br/comciencia/handler.php?section=8\&edicao=96\&id=1177 a> Acesso 22 mai. 2014

${ }^{18}$ ARAÚJO, Luiz Alberto David. Proteção Constitucional Do Direito A Própria Imagem. $2^{\text {a ed. }}$ Belo Horizonte: Verbatim, 2013. p. 23

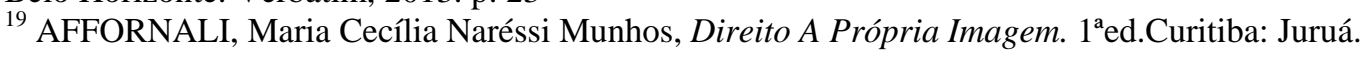
2012, p. 24

${ }^{20}$ MORAES, Walter Apud ARAÚJO, Luiz Alberto David. Proteção Constitucional Do Direito A Própria Imagem. 2aed. Belo Horizonte: Verbatim, 2013. p. 24

${ }^{21}$ Ibid. p. 24
} 
Neste sentido, há uma ampliação da noção de imagem para além daquela classicamente denotada. Sua tutela, embora mais aplicada ao campo fotográfico, pode ser aplicada também ao campo cinematográfico através da reprodução de determinado trejeito, linguagem gestual, atitude ou quaisquer outros sinais distintivos da sua personalidade retratada através de um ator.

A imagem-atributo seria uma decorrência lógica da vida em sociedade. Não se trata de restringir a imagem meramente ao retrato da pessoa, mas a associação de características que se fazem em relação a esta pessoa ganhando um conceito associado diretamente às relações sociais nas quais o indivíduo está envolvido. Esta é a imagem do profissional, do chefe de família e de outros arquétipos sociais que cercam a vida em sociedade ${ }^{22}$.

Como resultado de um produto em sociedade ela deve ser entendida como plural e embora tenha seu titular determinado, é visível que o seu conteúdo fica além do controle do titular. Ilustrando esta opinião, Celso Sabadin, diretor do filme Mazzaropi sobre Amácio Mazzaropi declara:

"Tem gente que diz que Mazzaropi era pão duro, tem gente que diz que era generoso. Tem gente que diz que ele era amigão de todos, tem gente que diz que ele era fechado e reservado, tem gente que diz que ele era genial, tem gente que diz que ele era meio tosco e assim por diante. Isso foi ótimo, pois mostra que Mazzaropi, acima de tudo, era uma pessoa comum, plural como todos nós, e não unidimensional $^{23}$,"

Conforme ressaltado anteriormente não somente o esteio material de reprodução da imagem, mas a própria influência dele na vida das pessoas que representa $^{24}$. Neste sentido Francesco Degni ${ }^{25}$ ensina:

\footnotetext{
${ }^{22}$ ARAÚJO, Luiz Alberto David. Proteção Constitucional Do Direito A Própria Imagem. $2^{\mathrm{a}} \mathrm{ed}$. Belo Horizonte: Verbatim, 2013. p. 27

${ }^{23}$ DELFINA, Cristiana, Generalizando a vida real. O que retratam as cinebiografias? Disponível em <http://www.comciencia.br/comciencia/handler.php?section=8\&edicao=96\&id=1177 a> Acesso 22 mai. 2014

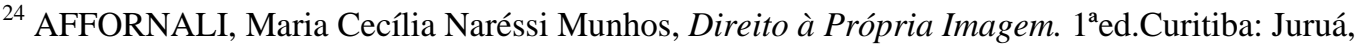
2012. p. 24

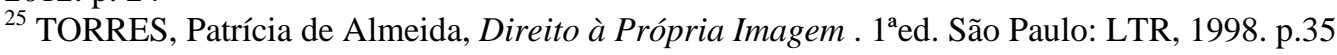


"Assim sendo, há que se falar na presença de duas imagens sob o prisma da proteção constitucional: a imagem-retrato, ligada a expressão física do indivíduo, $e$ a imagem-atributo ligada ao interesse que o indivíduo tem de ser bem visto pela sociedade em que se insere. Há que se ressaltar que a violação de uma não necessariamente implicaria na violação reflexa da outra ${ }^{26}$."

\subsection{A Imagem Como Bem Jurídico e seu Conteúdo}

Vale ressaltar que a imagem nem sempre foi considerada como um bem jurídico autônomo de modo que por diversas teve sua proteção atrelada a outros direitos pelas teorias negativistas do direito a imagem. Observe-se que estas qualificações estão atreladas a imagem-retrato, tradicionalmente preocupação da doutrina civilista, muito embora, ressaltados os aspectos relativos à honra, poderão ser estendidos a ambos os aspectos da imagem.

\subsubsection{A Imagem e o Direito à Honra.}

Para determinado grupo a imagem estaria na verdade tutelada pelo direito à honra, não havendo, portanto autonomia própria. A violação perpetrada contra a imagem implicaria necessariamente na violação da honra. Neste sentido, como ensina Walter de Moraes em citação por Luiz Alberto David Araújo, a imagem seria mais uma manifestação da moral e do seu decoro e sua reputação poderia ser violada a partir dele ${ }^{27}$.

Ocorre que esta teoria possui alguns equívocos. Há de se entender que a imagem pode ser ferida em hipóteses que a honra não seja atingida. Tomese por exemplo o caso em que a imagem de uma atleta de jiu jitsu serviu como imagem para propaganda de um torneio de judô, modalidade marcial diversa, sem que autorizasse o referido uso e, ainda que não tenha havido dano a honra da atleta, houve violação da sua imagem. Ou ainda, há a possibilidade de alguém se opor contra determinada propaganda em que o

\footnotetext{
${ }^{26}$ DEGNI, Francesco Apud TORRES, Patrícia de Almeida, Direito à Própria Imagem . $1^{\text {aed. São }}$ Paulo: LTR, 1998. p.35

${ }^{27}$ ARAÚJO, Luiz Alberto David. Proteção Constitucional Do Direito A Própria Imagem. $2^{\mathrm{a}} \mathrm{ed}$. Belo Horizonte: Verbatim, 2013. p.13
} 
indivíduo é retratado como homem virtuoso ${ }^{28}$. Ocorre que, embora a honra tenha permanecido intacta, a imagem foi vilipendiada.

Ainda, a própria imagem-atributo não se liga diretamente à honra. A visão que a sociedade tem do indivíduo não pode ser confundida com a honra de modo a se tratar de direito autônomo. Por exemplo, a reputação profissional de um determinado indivíduo como bom ou ruim em nada se liga com a honra ${ }^{29}$. Trata-se de característica própria não pressupondo um julgamento de bom ou ruim próprio de cada indivíduo, ou seja, não defronta-se aqui com o direito a honra .

\subsubsection{A Imagem e o Direito à Intimidade.}

Conforme define Luiz Alberto David Araújo, a vida íntima corresponde ao âmbito privado de cada indivíduo sendo, portanto vedada a intromissão de outrem. Para alguns autores a imagem se confundiria com a própria intimidade. Neste sentido Lindon Raymond ensina:

\footnotetext{
"Uma da manifestações importantes do direito ao resguardo é o chamado direito à imagem. Com a violação da imagem, o corpo e suas funções não sofrem alteração; mas verifica-se, relativamente à pessoa, uma modificação de caráter moral (circunspecção ou reserva, ou discrição pessoal, embora não faça parte da essência física da pessoa constitui uma qualidade moral dela) ${ }^{30}$.”
}

Esta opinião reducionista leva em consideração somente o direito à própria imagem, atinente a própria vida privada e a intimidade. Todavia, conforme já demonstrado o escopo de proteção do direito à imagem é mais abrangente do que o pressuposto por esta corrente. Tal acepção não há que

\footnotetext{
${ }^{28}$ MORAES, Walter Apud ARAÚJO, Luiz Alberto David. Proteção Constitucional Do Direito A Própria Imagem. $2^{\mathrm{a}}$ ed. Belo Horizonte: Verbatim, 2013. p. 31

${ }^{29}$ ARAÚJO, Luiz Alberto David. Proteção Constitucional Do Direito A Própria Imagem. $2^{\mathrm{a} e d .}$ Belo Horizonte: Verbatim, 2013. P. 31

${ }^{30}$ LINDON, Raymond Apud ARAÚJO, Luiz Alberto David. Proteção Constitucional Do Direito A Própria Imagem. $2^{\mathrm{a}}$ ed. Belo Horizonte: Verbatim, 2013. p. 33-34
} 
prevalecer porque nem em todas as hipóteses de violação do direito à imagem a intimidade será violada ${ }^{31}$.

Como bem ilustra J. Ravanas, há um ponto de interseção entre estes direitos que poderia apontar para uma eventual confusão entre eles:

" $O$ direito da pessoa sobre sua personalidade social parece apresentar uma doutrina jurídica dualista: a proteção do titular contra a desnaturalização de sua personalidade, em particular de sua personalidade social, é distinta do direito a vida privada; ao proteger seu titular contra a investigação e revelação através da imagem de esta parte de sua vida que o público não tem interesse legítimo em conhecer, se liga, com o direito à vida privada. ${ }^{32}$,"

Não há que se falar em identidade entre estes direitos. O direito à intimidade pretende amparar o titular de qualquer invasão de sua vida privada; já o direito à imagem atenta pela proibição da fixação de imagem do indivíduo em qualquer meio sem sua autorização e permite, ainda, sua exploração econômica pelo representado ainda que em determinados aspectos tenha a faculdade de proteger a vida privada do indivíduo.

Uma possível diferença a ser encontrada entre estes direitos, imagem e intimidade, teria apoio na pretensão individual que o direito a intimidade teria frente a um grupo determinado de pessoas enquanto o direito à imagem seria sempre uma pretensão erga omnes ${ }^{33}$.

Ilustrando esta separação, uma pessoa que faz de sua imagem seu instrumento de trabalho e, portanto, a utiliza em instrumentos de divulgação publicitária variada não poderia afirmar que houve violação de sua intimidade quando outra empresa utiliza sua imagem sem autorização. Seria hipótese meramente de violação do conteúdo material do direito da imagem

\footnotetext{
${ }^{31}$ AFFORNALI, Maria Cecília Naréssi Munhos, Direito A Própria Imagem. 1ªed.Curitiba: Juruá, 2012. p. 42.

${ }^{32}$ RAVANAS, Jaques Apud ASSENJO, Porfírio Barroso; TALAVERA, María del Mar López, La Libertad de Expresión y sus Limitaciones Constitucionales. Madrid: Fragua, 1998. P. 147tradução livre - p. 146

${ }^{33}$ ASSENJO, Porfírio Barroso; TALAVERA, María del Mar López, La Libertad de Expresión y sus Limitaciones Constitucionales. Madrid: Fragua, 1998. p. 147
} 
sem qualquer relação com violação da intimidade que possui um escopo mais reduzido em função de seu ofício ${ }^{34}$.

Ainda sobre a relação imagem-atributo e intimidade é visível que não há que se falar em um conteúdo diretamente relacionado entre ambos direitos. A imagem social de um indivíduo pode ser vilipendiada sem que haja qualquer violação da sua intimidade. Pense em um médico bem reputado em seu mercado da sua atuação e recebe uma acusação injusta de negligência. Nesta hipótese não há que se falar em qualquer violação de sua intimidade com base na divulgação caluniosa.

\subsubsection{A Imagem e o Direito à Identidade.}

Há um determinado grupo de autores que entendem que a imagem seria uma decorrência do direito à identidade correspondendo meramente à individualização figurativa da pessoa colocada como fator de identificação. Esta acepção se origina na aparência física como primeiro sinal distintivo da personalidade que se tem acesso ${ }^{35}$; não sem razão é o elemento utilizado em documentos de identificação. Desta forma, sempre que a imagem fosse publicada sem qualquer autorização do seu titular, seria hipótese de violação do direito à identidade ${ }^{36}$.

Ocorre que a reprodução não autorizada da imagem não implica na violação de imagem certamente, porém não há que se falar em perda da identidade uma vez que o titular da imagem permanecerá identificável.

\subsubsection{A Imagem e sua Autonomia.}

A imagem corresponde, portanto, a um direito totalmente autônomo sendo impossível posicioná-lo dentro da honra, intimidade ou identidade.

\footnotetext{
${ }^{34}$ ARAÚJO, Luiz Alberto David. Proteção Constitucional Do Direito A Própria Imagem. $2^{\mathrm{a}} \mathrm{ed}$. Belo Horizonte: Verbatim, 2013. p. 35

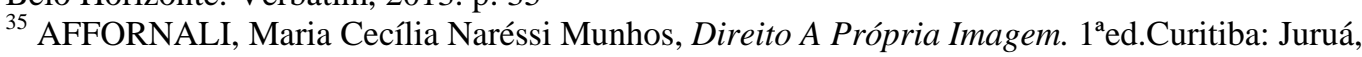
2012. p. 45
} 
Esta proteção não seria adequada as suas violações. Deste modo ensina Walter Moraes:

\begin{abstract}
"Se o bem da imagem constitui objeto autônomo de tutela jurídica que determina como facultas agendi um direito a ele, pois assim deve entender-se a faculdade exclusiva de permitir, proibir ou revogar-lhe a reprodução, a exposição etc., $e$ se este direito é oponível erga omnes, segue que o direito à imagem é direito absoluto. ${ }^{37}$,
\end{abstract}

A imagem é meio mais imediato de se imputar, também, determinadas qualidades às pessoas. A boa impressão que se tem acerca de alguém é devida fundamentalmente a sua imagem sendo, muitas vezes, o único padrão de valoração utilizado frente à sociedade. Neste sentido, sem sombra de dúvida possuir uma boa imagem é um facilitador na vida de cada pessoa e é lógico o seu interesse pessoal em mantê-la intacta.

Em função da imagem ser um ente abstrato, há dependência direta de um suporte físico para sua fixação. Desta forma, torna-se necessário a existência de aparatos técnicos capazes de reproduzir as características humanas. É possível então, afirmar que o avanço tecnológico constrói possibilidades mais dinâmicas de propagação da imagem, criando questionamentos impensáveis ao mundo onde a fixação da imagem dependia exclusivamente de meios artísticos como pintura e escultura que, além de dependerem da expertise do artista, demandavam tempo para serem elaborados.

A ascensão da televisão na década de 60 como veículo de comunicação de massa depende em muito da imagem captada por suporte audiovisual, sendo capaz de comunicar a notícia de modo muito mais célere e direto ${ }^{38}$. A dinamização da propagação massificada da imagem, em via oposta, muitas

\footnotetext{
${ }^{36}$ ARAÚJO, Luiz Alberto David. Proteção Constitucional Do Direito A Própria Imagem. $2^{\mathrm{a}} \mathrm{ed}$. Belo Horizonte: Verbatim, 2013. p. 36

${ }^{37}$ MORAES, Walter Apud ARAÚJO, Luiz Alberto David. Proteção Constitucional Do Direito A Própria Imagem. $2^{\mathrm{a} e d}$. Belo Horizonte: Verbatim, 2013. p. 37

${ }^{38}$ AFFORNALI, Maria Cecília Naréssi Munhos, Direito A Própria Imagem. 1ªed.Curitiba: Juruá, 2012. p. 36
} 
vezes feita de maneira irresponsável e indiscriminada, suscita eventuais prejuízos ao titular do direito à imagem e seu conteúdo.

Há que se falar no duplo conteúdo do direito à imagem ${ }^{39}$, moral e material. O conteúdo moral diz respeito à possibilidade do titular de impedir a circulação de sua imagem e o conteúdo material se refere à exploração econômica de sua própria imagem. Assim, é lógica a dedução de que o direito em exame visa, além da proteção do interesse moral de impedir sua representação, o representado também poderia impedir a fixação e a divulgação e a sua privacidade.

\subsubsection{A Imagem como Direito da Personalidade.}

Ao categorizar-se o direito de imagem como Direito da Personalidade , cristaliza-se como pedra fundamental o caráter extrapatrimonial conforme já explorado no capítulo anterior. Sobre esta característica Walter Moraes afirma:

\footnotetext{
"Como bem essencial, a imagem determina uma regra categórica, isto é, uma regra de dever geral de não violação e preservação, correspondente a um direito absoluto cujo o exercício constante é intrinsecamente garantido pela essencialidade do bem $e$, concomitantemente, irrenunciabilidade do direito. Nisso, alias, distinguem-se os direitos reais dos direitos da personalidade em que estes são imprescindíveis para o sujeito porque têm por objeto um bem jurídico essencial à personalidade, e daqueles pode prescindir-se, pois importam em objetos estranhos à estrutura pessoal ${ }^{40}$."
}

Causa estranheza o elemento material que faculta ao titular a exploração econômica do seu sinal distintivo da personalidade. A doutrina civilista alega que o conteúdo patrimonial não implicaria na possibilidade de transferência do direito, mas em uma permissão ou uso condicionado pelo titular.

Vale ressaltar que a interpretação atualmente dada ao aspecto patrimonial e ao aspecto material sob a ótica patrimonialista do direito de

\footnotetext{
${ }^{39}$ Ibid. p. 37
} 
imagem vem gerando distorções de graves resultados a memória coletiva. Ou seja, dá ensejo a uma retirada do conteúdo de publicação baseada na aplicação do conteúdo material do direito à imagem meramente pela ausência de uma "negociação" conforme mencionado anteriormente no episódio da biografia do sambista Noel Rosa.

Note-se, o que está em questão não é a reparação de danos eventualmente gerados à imagem, mas a censura exercida meramente por um viés econômico do direito do titular da imagem ou de seus herdeiros, ou seja, a falta de uma contraprestação economicamente apreciável equiparando o direito da personalidade a mero direito subjetivo.

\subsection{Características do Direito à Imagem}

O direito à imagem é espécie de direito da personalidade, e desta maneira possui determinadas posições de destaque frente a outros direitos. Neste sentido, possui uma série de características próprias que merecem abordagem para a compreensão do seu escopo de proteção, isto é, sem estas características a sua proteção e, em última análise, a ideia de pessoa estaria ameaçada.

Trata-se de direito oponível erga omnes, de maneira que todos são obrigados a respeitá-los, de modo que sua violação não seria permitida nem ao Estado nem a outros indivíduos cabendo ao primeiro, inclusive garantir esta oponibilidade. É também direito geral por pertencer a cada um individualmente e essencial pois sua inexistência ameaçaria a noção de personalidade ${ }^{41}$.

Há que se falar na intransmissibilidade do direito à imagem, que tem seu fundamento na impossibilidade de separar a honra e a intimidade de seu titular. Sua própria natureza é o que torna intransmissível o bem. Não é possível que um indivíduo se desfaça da sua imagem ou mesmo da sua

\footnotetext{
40 MORAES, Walter Apud ARAÚJO, Luiz Alberto David. Proteção Constitucional Do Direito A Própria Imagem. $2^{\mathrm{a}}$ ed. Belo Horizonte: Verbatim, 2013. p. 38/39

${ }^{41}$ Ibid. p. 49
} 
imagem-atributo. No máximo ele poderia pretender modificá-las deixando de ser visto por determinada característica, mas não há que se falar em abrir mão da própria imagem ${ }^{42}$.

Em paralelo à sua intransmissibilidade, cabe também falar de indisponibilidade, isto é, possui um grau de fruição reduzido dado às menores peculiaridades do bem. Porém, esta indisponibilidade é mitigada vez que o direito à imagem é passível de exploração econômica, encontrando uma especificação mais restritiva a respeito desta característica, se distanciando do escopo de proteção que os demais direitos da personalidade gozam.

Retomando o duplo conteúdo do direito à imagem, não há que se afastar a preponderância do direito do interesse moral do seu titular. Os seus reflexos econômicos decorrem da veiculação da imagem em meios publicitários, audiovisuais e demais bem, como da própria pretensão pecuniária que surge a partir da sua violação ${ }^{43}$.

A morte do titular do direito à imagem implica a seus sucessores a faculdade de vedar ou permitir a reprodução da imagem do de cujus. Não se pode falar, todavia, em uma transmissão do direito à imagem em função do seu tom personalíssimo. Ou seja, há o surgimento de um direito de titularidade dos herdeiros do morto que não goza de todas prerrogativas de direito de imagem ${ }^{44}$, tema este que será aprofundado no próximo tópico.

$\mathrm{O}$ direito remanescente à morte do titular não deve ser equiparado a sua personalidade pois, como ensina a doutrina, a personalidade se inicia com o nascimento e se extingue com a morte do indivíduo. O que ocorre após a morte é a permanência de determinados interesses e direitos a serem protegidos $^{45}$ em nome do morto. Assim sendo, o interesse de herdeiros e a visão patrimonial que possuem sobre esta imagem não faria sentido.

\footnotetext{
${ }^{42}$ DOSSE, François - O Desafio Biográfico: Escrever uma vida. $1^{\text {a }}$ ed. São Paulo: EdUSP.2009 p. 40

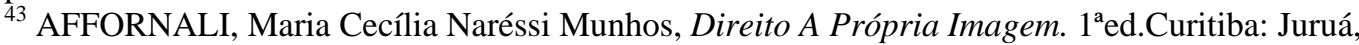
2012. p. 51

${ }^{44}$ Ibid. p. 52

${ }^{45}$ TORRES, Patrícia de Almeida, Direito à Própria Imagem . 1ªed. São Paulo: LTR, 1998. p.77/78
} 


\subsection{A Proteção Constitucional do Direito à Própria Imagem}

Pretendo aqui aprofundar a discussão iniciada no capítulo anterior a respeito da tutela que os direitos da personalidade recebem do ordenamento jurídico, porém focalizada, agora, no direito à imagem, ponto central na discussão sobre as cinebiografias, e suas peculiaridades para que posteriormente passemos a analisar seus impactos na atuação da ANCINE frente às cinebiografias. Inovando frente às Constituições anteriores, a imagem veio protegida na Constituição Brasileira de 1988 incluindo no sentido de adotar critérios para quantificação e reparação do dano à imagem.

Conforme a questão da autonomia dos direitos à imagem supra desenvolvida, a CRFB/88 logrou êxito em posicionar o direito à imagem lado a lado com diversos bens jurídicos como intimidade, privacidade e honra no inciso $\mathrm{X}$ do seu artigo $5^{\circ}$. Desta forma, assegurou a autonomia do direito à imagem, pondo ponto final à discussão doutrinária. Ou seja, a imagem constitui bem jurídico autônomo apartado da intimidade, da honra e da vida privada; caso assim não fosse, não haveria razão de posicioná-la ao lado de outros bens.

Assim sendo, a imagem deve ter tratamento próprio ao lado da intimidade, da honra e da privacidade. Desta forma, a legislação infra constitucional deve preservar a autonomia do bem debatido quando elaborar seu exercício negando qualquer posicionamento no sentido de abolir a autonomia do Direito à Imagem ${ }^{46}$.

Ressalte-se que o texto constitucional não tratou do apenas da imagemretrato ao conceder-lhe autonomia, mas também da imagem-atributo. Não há que se enquadrar a imagem atributo dentre os outros bens. Neste sentido é correto afirmar que a imagem recebe dupla proteção: como imagemretrato, acepção clássica do direito à imagem, entre a honra, intimidade e

\footnotetext{
${ }^{46}$ ARAÚJO, Luiz Alberto David. Proteção Constitucional Do Direito A Própria Imagem. $2^{\mathrm{a}} \mathrm{ed}$. Belo Horizonte: Verbatim, 2013. p. 66
} 
vida privada, e como imagem-atributo posicionada lado a lado do direito de resposta $^{47}$.

\subsubsection{A Proteção Constitucional do Direito à Imagem-Retrato}

A inviolabilidade prevista para a imagem no inciso $\mathrm{X}$ do artigo $5^{\circ}$ da Constituição permite concluir-se que a utilização indevida da imagemretrato permitirá a oposição pelo seu titular. Como utilização indevida deve ser entendida de modo aberto, sem quaisquer limitações taxativas a seu exercício. Como exemplo de uso indevido da imagem pode-se citar a publicação publicitária de um retrato sem a autorização de seu titular ou a utilização da imagem de um terceiro para identificar a si próprio.

Conforme já introduzido anteriormente, o direito à própria imagem em função de seu caráter de direito da personalidade é intransmissível, pois se extingue com a morte do indivíduo da mesma maneira que surge com seu nascimento. Com a morte do titular do direito à própria imagem surge, contudo, para os seus herdeiros um direito diferente do originário mas com o escopo de protegê-los da veiculação da imagem do de cujus.

$\mathrm{O}$ direito neste sentido, não corresponde à própria imagem mas à honra, intimidade e vida privada vez que aquele se extinguiu com a morte do indivíduo. A imagem deixa, então, de ser protegida diretamente, mas serviria de suporte para a proteção de outro direito ${ }^{48}$. Trazida ao enfoque pelo Código Civil no artigo 20, páragrafo único, a autorização dos descendentes para que a imagem possa ser veiculada é expressamente exigida. Em que pese a constitucionalidade duvidosa do artigo, já abordada e que será retomada à frente sob a ótica do direito à imagem, o direito de manifestação e a liberdade de comunicação encontram-se tolhidos frequentemente frente a este dispositivo.

O exercício do direito à imagem-retrato encontra seu limite expressos pela própria ordem pública ou eventualmente por outro bem jurídico de

\footnotetext{
${ }^{47}$ Ibid. p. 66
} 
igual intensidade. Desta forma, em determinadas situações, mesmo sem autorização do indivíduo, é possível que a imagem seja violada, embora o direito pátrio não inclua, a princípio, a liberdade de informação nos fundamentos possíveis para uma quebra do direito à imagem ${ }^{49}$.

Um exemplo típico, da possibilidade desta violação diz respeito a segurança nacional. Isto é, o titular do direito em tela não poderia se opor à publicação da sua imagem se o prejuízo gerado pela não publicação atingirá a própria estabilidade nacional ${ }^{50}$.

Outro exemplo diria respeito ao interesse da história, neste sentido Luiz Alberto David Araújo dispõe:

\footnotetext{
“O interesse da história é outro motivo para a exclusão do direito à imagem. Certas personagens, mesmo vivas, não podem se opor à publicação de suas imagens, se dentro de um contexto de narrativa histórica tiverem um papel de importância. Não teria sentido, por exemplo, um ex- Presidente da República pretender evitar a publicação de sua fotografia, em livro de interesse histórico. No entano, o texto há de se restringir à matéria em foco, não podendo, a pretexto da situação excepcional da proteção divulgar a imagem sem a correta informação histórica ${ }^{51 \text { ”, }}$
}

Cumpre, portanto, ressaltar que as (Cine)biografias se enquadram como instrumento importantíssimo de preservação do direito a memória e do direito à história, por vezes sendo colocadas associadas exclusivamente ao direito a informação de maneira equivocada.

\subsubsection{A Proteção Constitucional do Direito à Imagem-Atributo}

O inciso V do art. $5^{\circ}$ da Constituição Federal dispõe:

"V- é assegurado o direito de reposta, proporcional ao agravo, além da indenização por dano material, moral ou à imagem."

\footnotetext{
${ }^{48}$ Ibid. p. 78

${ }^{49} \mathrm{O}$ artigo 220 da CRFB dispõe no sentido de, em confronto entre liberdade de expressão e de informação e o direito de imagem, na preponderância do segundo

${ }^{50}$ ARAÚJO, Luiz Alberto David. Proteção Constitucional Do Direito A Própria Imagem. $2^{\mathrm{a}} \mathrm{ed}$.

Belo Horizonte: Verbatim, 2013. p. 86

${ }^{51}$ Ibid. p. 87
} 
A imagem tutelada neste artigo diz respeito a imagem-atributo, conjunto de características sociais do indivíduo, vez que é clara a proteção à imagem-retrato no inciso $\mathrm{X}$ do referido artigo não havendo, portanto, necessidade de ressaltá-la. Tais características nem sempre serão louváveis, conforme já mencionado. Os danos gerados, neste caso, são fundamentalmente pelos meios de comunicação e mídia. E neste sentido sua tutela e proteção adequada se encontram resguardadas pelo direito de resposta previsto neste inciso ${ }^{52}$.

O direito à resposta encontra relação direta com o direito à informação. Assim, o meio pelo qual a notícia ou o dado sobre a pessoa corre deve ser correta no sentido de evitar equívocos a respeito do titular da imagematributo. O fim a que se pretende o direito de resposta, portanto, é de ser um instrumento apto a evitar que o titular do direito tenha sua imagem vilipendiada por informações imprecisas ou inverídicas a seu próprio respeito, correspondendo ao meio adequado para retificar informações a seu respeito.

Em uma definição possível Antônio Costella dispõe que direito de resposta é a garantia que a lei dá a cada um de apresentar a sua versão dos fatos, pelo mesmo veículo, quando tenha sido ofendido, acusado ou vítima de erro nos meios de comunicação de massa ${ }^{53}$.

Neste sentido cumpre ressaltar que o direito de resposta se ergue com autonomia frente à indenização. Ou seja, não necessariamente a aplicação do direito de resposta deve estar atrelada a uma reparação pecuniariamente apreciável. A jurisprudência pátria em muito subestima a aplicação do direito de resposta apontando a indenização como viés adequado a violação dos direitos previstos no inciso $\mathrm{V}$.

Note-se, a indenização pecuniária, diversas vezes provoca o que a doutrina americana chama de chilling effect, isto é, em função da falta de

\footnotetext{
${ }^{52}$ Ibid. p. 100

${ }^{53}$ COSTELLA, Antônio Apud ARAÚJO, Luiz Alberto David. Proteção Constitucional Do

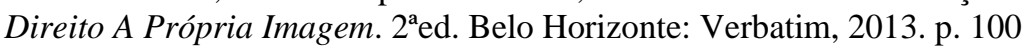


recursos para pagar uma indenização, deixa-se de suscitar determinada discussão em função extinguindo, em última análise, a discussão.

\subsection{O Conflito do Direito à Própria Imagem e da Liberdade de Expressão e Comunicação}

O acórdão da apelação do processo promovido pela irmã herdeira da atriz conhecida como Luz Del Fuego, contra produtores da cinebiografia que seria exibido sem o seu consentimento resultou na votação unânime pelo TJ RJ no sentido de que parentes do morto não possuem direito à imagem. Analise-se a ementa da Apelação Cível 39.193/TJRJ:

\section{“DIREITO DA PERSONALIDADE. VIOLAÇÃO}

1- Toda pessoa tem direito ao resguardo, aí compreendidos os atos de sua vida, ainda que durante esta haja adquirido notoriedade, hipótese em que a divulgação de fatos para a composição de biografia, admissivel por obséquio aos interesses históricos e científicos, não abrange a forma romanceada.

2- Com a morte da pessoa, seus parentes próximos podem se opor a divulgação da vida do extinto, não por transferência dos direitos da personalidade, mas por direito próprio.”

Neste sentido, embora anterior ao CC/2002 o acórdão encontra-se respaldado pelos artigos $20^{54}$ e $21^{55}$ do diploma legal. De antemão cumpre ressaltar que a própria escolha de palavras deste artigo foi feita sem a cautela que deveria ter sido adotada. O texto do artigo fala em honra, respeitabilidade e em boa fama. Destas, apenas a expressão honra encontra respaldo no texto constitucional ${ }^{56}$. A evidente desconexão entre as terminologias adotadas revela a distância da matriz constitucional à qual o tema deve se submeter.

\footnotetext{
${ }^{54}$ Art. 20 - Salvo se autorizadas, ou se necessárias à administração da justiça ou à manutenção da ordem pública, a divulgação de escritos, a transmissão da palavra, ou a publicação, a exposição ou a utilização da imagem de uma pessoa poderão ser proibidas, a seu requerimento e sem prejuízo da indenização que couber, se lhe atingirem a honra, a boa fama ou a respeitabilidade, ou se se destinarem a fins comerciais.

${ }^{55}$ Art. 21. A vida privada da pessoa natural é inviolável, e o juiz, a requerimento do interessado, adotará as providências necessárias para impedir ou fazer cessar ato contrário a esta norma.

${ }^{56}$ ARAÚJO, Luiz Alberto David. Proteção Constitucional Do Direito A Própria Imagem. $2^{\mathrm{a}} \mathrm{ed}$. Belo Horizonte: Verbatim, 2013. p.114
} 
Enfatiza-se ainda, que a vedação à forma romanceada da (Cine)biografia é um grande equívoco. Esta vedação tem por intuito evitar distorções acerca do indivíduo retratado na biografia, porém toda biografia, não importando sua natureza, possui um grande dado de subjetividade do autor a fim de preencher as lacunas que a pesquisa não permite, conforme já mencionado. Desta maneira, o próprio documentário possui, em algum nível, subjetividade do seu autor para preencher a história manifestada de modo diverso da dramaticidade.

Todo sujeito de direito pode, legitimamente, exercer o direito de informar a seu título pessoal sobre a imagem de outrem. Por outro lado, outro indivíduo que por alguma razão projete sua imagem ao público, tirando-a do aspecto meramente privado de sua vida, implica na conversão em direito passivo à informação de outros ${ }^{57}$. Assim, esta relação entre o direito do indivíduo sobre sua imagem e o direito do público sobre esta mesma imagem diretamente ligado ao seu direito de ser informado, implicará na defesa de um em detrimento do outro em um caso prático.

Neste contexto, somente as particularidades do caso prático podem determinar os limites de cada direito bem como as sanções que eventualmente o violador do direito a imagem virá a sofrer. Portanto a proibição de veiculação associada à autorização para retirada de circulação da mídia utilizada e até mesmo a proibição da fixação da imagem são punições exacerbadas às violações do direito de imagem devendo ser tratadas de modo cauteloso pelo direito pátrio.

Não se trata, também, de colocar a imagem como uma barreira inexpurgável ao direito à comunicação e informação vez que a própria imagem acaba por tutelada diversas vezes pela própria liberdade de informação passiva e ativa. De acordo com o autor Daniel Becourto direito

\footnotetext{
${ }^{57}$ ASSENJO, Porfírio Barroso; TALAVERA, María del Mar López, La Libertad de Expresión y sus Limitaciones Constitucionales. Madrid: Fragua, 1998. p. 157
} 
à imagem somente existe enquanto limite ao direito fundamental à informação ${ }^{58}$. Desta forma não poderia ser um impedimento absoluto.

O legislador constitucional foi infeliz, também, ao editar o artigo 220 da CRFB com o seguinte conteúdo:

"Art.220 - A manifestação do pensamento, a criação, a expressão e a informação, sob qualquer forma, o processo ou veículo não sofrerão qualquer restrição, observando o disposto nesta constituição.

Parágrafo $1^{\circ}$ - Nenhuma lei conterá dispositivo que possa constituir embaraço a plena liberdade de informação jornalística em qualquer veículo de comunicação social, observando o disposto no art. $5^{\circ} \mathrm{X}, \mathrm{V}$, VIII e XIV.”

Neste artigo o poder constituinte traçou uma orientação aos aplicadores do direito no sentido de, em caso de confronto, optar pelo prevalecimento do direito à imagem sobre o direito a informação ${ }^{59}$. Ou seja, cria na prática hierarquia constitucional entre estes direitos. Assim, acaba por constituir um cenário propício à retirada de circulação cautelar inclusive para divulgação de quaisquer supostas ofensas ao direito de imagem.

Em sentido diverso, coloca Silvio Venosa a respeito da suposta hierarquia entre estes direitos:

\begin{abstract}
"Sem dúvida a imagem da pessoa é uma das principais projeções de nossa personalidade e atributo fundamental dos direitos ditos personalíssimos. $O$ uso indevido da imagem traz, de fato, situações de prejuízo e constrangimento. No entanto, em cada situação é preciso avaliar se, de fato, há abuso na divulgação da imagem. Nem sempre a simples divulgação de uma imagem é indevida, doutra forma seria inviável noticiário televisivo, jornalístico ou similar. ${ }^{60,}$
\end{abstract}

No mesmo sentido se manifesta Luiz Alberto David Araújo sobre o conflito entre liberdade de expressão e informação e direito à imagemretrato:

\footnotetext{
${ }^{58}$ BECOURT, Daniel ApudASSENJO, Porfírio Barroso; TALAVERA, María del Mar López, La Libertad de Expresión y sus Limitaciones Constitucionales. Madrid: Fragua, 1998. p. 157

${ }^{59}$ ASSENJO, Porfírio Barroso; TALAVERA, María del Mar López, La Libertad de Expresión y sus Limitaciones Constitucionales. Madrid: Fragua, 1998. p. 74

${ }^{60}$ VENOSA, Silvio ApudARAÚJO, Luiz Alberto David. Proteção Constitucional Do Direito A Própria Imagem. 2ªd. Belo Horizonte: Verbatim, 2013. p. 116
} 
"Não se pode deixar de mencionar, como motivo para a limitação do direito a própria imagem, o interesse do noticiário pelas denominadas figuras públicas. São indivíduos que, em razão do ângulo artístico, político, esportivo ou por qualquer outro motivo, protejam sua personalidade para além das barreiras individuais, passando a ser objeto de interesse público, interesse de toda comunidade. São pessoas que são notícias dos jornais, das revistas especializadas, das reportagens. ${ }^{61,}$

Ora, neste sentido cumpre ressaltar que os objetos das biografias de toda sorte são justamente pessoas públicas de relevância em determinado meio. Assim sendo, haveria de se entender, inclusive, pela mitigação da restrição existente no artigo 20 do Código Civil, que as (Cine)biografias apenas constituem veículos alternativos a difusão da informação de extrema importância, visando a criação de uma memória histórica coletiva.

\footnotetext{
${ }^{61}$ ARAÚJO, Luiz Alberto David. Proteção Constitucional Do Direito A Própria Imagem. $2^{\mathrm{a}} \mathrm{ed}$. Belo Horizonte: Verbatim, 2013. p. 88
} 


\section{A Atuação da ANCINE no Mercado das (Cine)biografias.}

O cinema, como meio de expressão artística e cultural de um povo cada vez mais se consolida como veículo de comunicações de massas sendo, portanto, meio importantíssimo para firmar a memória de uma determinada nação. O cinema se apresenta de forma mais dinâmica e atinge um público sensivelmente maior que o mercado da literatura, o que é de extrema importância em um país com índices sofríveis de educação como o Brasil.

A indústria cinematográfica se desenvolve em quatro segmentos distintos: produção ${ }^{62}$, infra-estrutura ${ }^{63}$, distribuição ${ }^{64}$ e exibição ${ }^{65}$. Trata-se, também de uma atividade na qual o processo produtivo é demorado e o produto final (filme) chega ao seu destino (janelas de exibição) no prazo médio de um a três anos, dependendo, muitas vezes, do porte e do grau de consolidação da empresa produtora no setor.

A dinâmica da produção cinematográfica, não só no Brasil, mas em um número grande de países, é dependente de políticas de incentivo à produção, bem como fica à mercê das características dos governos para seu funcionamento ${ }^{66}$.

Em 1969 foi instituída a Empresa Brasileira de Filmes (EMBRAFILME), empresa estatal que tinha a finalidade inicial de divulgar o cinema brasileiro no exterior, parte da propaganda nacionalista implementada pelo governo militar, mas este objetivo foi sendo gradualmente transformado. No ano de 1975, em pleno período de "milagre econômico brasileiro", uma reforma na empresa modificou seu perfil e a tornou-a mais ágil para a disputa no mercado cinematográfico, produzindo e distribuindo filmes brasileiros. Durante os anos seguintes, a produção nacional promovida pela empresa foi expressiva, tendo conquistado cerca

\footnotetext{
${ }^{62}$ Empresas responsáveis pela elaboração e desenvolvimento dos filmes.

${ }^{63}$ Empresas que alugam cenários, equipamentos e infra-estrutura às empresas produtoras.

${ }^{64}$ Empresas que ligam às produtoras e as diferentes “janelas” de exibição.

${ }^{65}$ Empresas responsáveis pela exibição comercial dos filmes nas salas de cinema.

${ }^{66}$ MICHEL, Rodrigo Cavalcante; AVELLAR, Ana Paula. A indústria cinematográfica brasileira:
} 
de quarenta por cento do mercado. Além de atuar como distribuidora de filmes nacionais, ainda cumulava o papel de fomentadora do mercado cinematográfico nacional.

O declínio da EMBRAFILME ocorreu de forma gradativa decorrente de diversos fatores dentre os quais podemos citar a crise econômica da década de 80 e sucessivos problemas de má gestão. A instituição foi perdendo suas funções até sua extinção em 1990, movimento do governo Collor que, através da MP 151/90, pôs fim aos incentivos governamentais na área cultural, mostrando que o setor cultural deveria dali em diante ser regido pelas leis de mercado.

A viabilização de um filme ficava restrita à iniciativa privada somente, sem nenhum apoio, sendo que o ideal de um cinema que refletisse a cultura brasileira e caminhasse no sentido de uma identificação popular foi bruscamente rompido. É nesse período que melhor pode-se observar a dependência da indústria cinematográfica em relação ao Estado e dos mecanismos de fomento. Com a extinção da EMBRAFILME determinante da dinâmica do setor, a resposta no desempenho da indústria cinematográfica foi praticamente imediata.

A produção nacional ficou paralisada na quase a totalidade das produções longa-metragem nacional, ainda que em 1990 e 1991 houvesse um número razoável de filmes brasileiros lançados comercialmente como resultado de produções iniciadas no período anterior. Para tanto, basta comparar os dados da década de 70 em que a produção nacional se aproximou de 35\% do mercado interno com uma produção média de 100 filmes por ano com a de 1992, de apenas três filmes lançados neste ano, o que corresponde a menos de $2 \%$ do mercado ${ }^{67}$.

uma análise da dinâmica da produção e da concentração industrial . Revista de Economia da UFPR, p. 35-53, jan./abr. 2012. p.36

${ }^{67}$ IKEDA, Marcelo. O Art. $3^{\circ}$ da Lei do Audiovisual e as Políticas Públicas Para o Setor Audiovisual na retomada. - Disponível em $<$ http://www.direitosculturais.com.br/ojs/index.php/ojs/article/ viewFile/278/169> acessado em 01 mai. 2014. 
A Lei do Audiovisual, em 1993, foi instrumentos de extrema relevância para o restabelecimento da produção cinematográfica brasileira e, de certa forma, serviu como uma nova esperança para os cineastas. Por meio delas o governo criou uma série medidas de incentivos fiscais às pessoas físicas e jurídicas com a finalidade de atrair o investimento de empresas nacionais e internacionais para as atividades culturais. A partir de 1996 a produção volta a se recuperar, em decorrência da implantação de políticas que estimulam a produção através de incentivos fiscais.

O apoio do Estado aos projetos cinematográficos passou a ocorrer de uma forma diferente da anterior com a Lei do Audiovisual, num modelo distinto do ciclo, com a criação dos mecanismos de incentivo, baseados em renúncia fiscal, em que pessoas físicas ou jurídicas realizam o aporte de capital num determinado projeto, sendo que o valor era abatido - parcial ou integralmente - no imposto de renda devido. Desta forma, o Estado continuava as estimular todo processo de produção cinematográfica, mas ampliava a participação dos agentes de mercado como parte intrínseca desse modelo.

O Estado inicia a atuação no processo de desenvolvimento do audiovisual brasileiro de forma indireta, estimulando a ação de terceiros, sem intervir diretamente no processo econômico, sem participar da produção ou distribuição dos filmes. Apesar de os recursos em última análise terem origem no capital estatal, vez que a origem da verba se daria através de renúncia fiscal, a decisão de investir e a escolha dos projetos partiam de empresas do setor privado, cujo negócio não necessariamente estaria atrelado à atividade audiovisual.

A partir de uma demanda do setor materializada na luta pela criação e consolidação de um modelo genuinamente nacional de cinema, organizouse e desenvolveu-se a proposta de uma agência reguladora para o mercado cinematográfico durante o Congresso Brasileiro de Cinema realizado em Porto Alegre, em 2000, e no Rio de Janeiro, no ano seguinte. Neste sentido a política nacional do cinema estabelecida pela MP 2228-1/01 no seu artigo 
$2^{\circ}$ aponta dentre seus princípios gerais a promoção da cultura nacional e da língua portuguesa mediante o estímulo ao desenvolvimento da indústria cinematográfica e audiovisual nacional e cria a Agência Nacional do Cinema (ANCINE) com as competências enumeradas no artigo $7^{\circ}$ da referida Medida Provisória:

\begin{abstract}
Art7 $7^{\circ}$ - A Ancine terá as seguintes competências: executar a política nacional de fomento ao cinema, definida na forma do art. 3o; fiscalizar o cumprimento da legislação referente à atividade cinematográfica e videofonográfica nacional e estrangeira nos diversos segmentos de mercados, na forma do regulamento; promover o combate à pirataria de obras audiovisuais; aplicar multas e sanções, na forma da lei; regular, na forma da lei, as atividades de fomento e proteção à indústria cinematográfica e videofonográfica nacional, resguardando a livre manifestação do pensamento, da criação, da expressão da informação; coordenar as ações e atividades governamentais referentes à indústria cinematográfica e videofonográfica, ressalvadas as competências dos Ministérios da Cultura e das Comunicações.
\end{abstract}

A ANCINE é a autarquia que tem por caráter exercer regulação do mercado cinematográfico através de atos regulatórios e fiscalizatórios bem como tem o papel de fomentar a indústria cinematográfica em âmbito nacional. Vinculada ao Ministério da Cultura, a Agência se propõe a estimular o crescimento do mercado audiovisual interno, através de mecanismos de expansão da oferta e demanda por conteúdos plurais e diversificados.

A autarquia pretende também, através de diversos mecanismos, consolidar as empresas de capital nacional comprometidas com a produção audiovisual brasileira e auxiliar as produções nacionais a melhor se inserirem no mercado estrangeiro, através do apoio à coproduções e à participação em festivais internacionais. Isso se dá através de diferentes mecanismos, diretos e indiretos.

Neste sentido a atuação da ANCINE como fomentadora financeira da produção nacional cinematográfico ocorre principalmente através de dois mecanismos: O Fundo Setorial Audiovisual e a Lei do Audiovisual. 


\subsection{A Estrutura do Fundo Setorial Audiovisual (FSA) e a exigência de autorização do uso de imagem.}

O Fundo Setorial Audiovisual (FSA), categoria específica do Fundo Nacional de Cultura (FNC), corresponde a um fundo destinado ao desenvolvimento de toda cadeia produtiva atrelada ao mercado cinematográfico nacional criado pela Lei 11.437/06. Entre seus principais objetivos destacam-se o incremento da cooperação entre os diversos agentes econômicos, a ampliação e diversificação da infra-estrutura de serviços, o fortalecimento da pesquisa e da inovação no setor cinematográfico, o crescimento sustentável da participação de mercado do conteúdo nacional e o desenvolvimento de novos meios de difusão da produção audiovisual brasileira. O FSA tem por intuito assegurar um aumento da oferta das produções audiovisuais nacionais.

Note-se que, dos 83 longa metragens brasileiros lançados em $2012^{68}$, $\operatorname{todos}^{69}$ foram financiados com a renda pública de alguma natureza. Isto ilustra a fragilidade do mercado cinematográfico e a particular situação em que o produtor independente de grandes veículos de mídia enfrentam diariamente.

Os recursos que compõem o FSA são fundamentalmente oriundos da arrecadação da CONDECINE - Contribuição para o Desenvolvimento da Indústria Cinematográfica Nacional, tributo gerado sobre a veiculação, a produção, o licenciamento e a distribuição de obras cinematográficas e videofonográficas com fins comerciais, também denominada como CONDECINE Título, bem como da sua outra modalidade, conhecida como CONDECINE Remessa nos termos do artigo 1o da Lei 11.437/06. Outra receita do FSA corresponde à parcela da arrecadação do FISTEL - Fundo

\footnotetext{
${ }^{68}$ Dados retirados do anuário da ANCINE de 2012 disponíveis no domínio $<$ http://issuu.com/oca_ancine/ docs/anuario_2012> acesso em 01 mai.2014.

${ }^{69}$ Dados retirados da listagem completa de Valores Captados por Mecanismos de Incentivo e Projeto-1995 a 2012 disponíveis em

<http://oca.ancine.gov.br/media/SAM/DadosMercado/2408.pdf> acesso em 01 mai.2014.
} 
de Fiscalização das Telecomunicações, conforme disposto no artigo 20 da Lei 11. 437/06.

Neste sentido, o Fundo Setorial do Audiovisual possui programas direcionados a todos os segmentos da indústria audiovisual. Para o presente estudo, o foco será o Programa de Apoio ao Desenvolvimento do Cinema Brasileiro (PRODECINE), previsto no art. 4o, inciso I, da Lei 11.437/06, na Linha A que diz respeito à produção cinematográfica nacional exclusivamente (PRODECINE A). Desta forma a verba obtida através do PRODECINE pode ser utilizadas das seguintes formas seguintes formas:

- Investimento - Participação em projetos, tendo como contrapartida a participação do FSA nos resultados comerciais dos mesmos, e no capital de empresas (participação minoritária). Nessa modalidade de colaboração financeira, os recursos aplicados pelo FSA são retornáveis, porém não exigíveis.

- Financiamento - Operações de empréstimo a projetos, mediante a constituição de garantias e tendo como contrapartida o pagamento de encargos financeiros, com plena exigibilidade dos recursos;

- Equalização - Redução de encargos financeiros incidentes em operações de financiamento;

- Valores não-reembolsáveis - Modalidade de colaboração financeira prevista apenas em casos excepcionais, mediante a prévia aprovação do Comitê Gestor do Fundo Setorial Audiovisual (CGFSA).

Isto significa que o FSA funciona como um fundo de investimento voltado ao incentivo da produção nacional que, sem ele, restaria radicalmente diminuída. É a oportunidade que empresas sem grande capital atrelado a si possam também participar da produção de maneira a assegurar um verdadeiro pluralismo do cinema nacional.

O acesso a este financiamento possibilitado pelo PRODECINE A se dá através da inscrição de produtores interessados em concursos públicos pautados por editais elaborados pela ANCINE. Sua participação se dará após a aprovação do Comitê Gestor do FSA, órgão misto composto por 
membros do Ministério da Cultura e pela ANCINE, nos termos do artigo $5^{\circ}$ da Lei 11. 437/06 ${ }^{70}$, dos valores investidos na obra.

Para que possa se valer dos benefícios do PRODECINE A, foi exigido em todos editais desde o primeiro em 2008, que os proponentes fossem Produtoras Brasileiras Independentes. Esta definição que não encontrava abrigo na legislação foi consolidada pela Instrução Normativa 104/2012 da ANCINE dispõe o seguinte:

Art. 10 - Para fins desta Instrução Normativa, entende-se como:

XLII. Produtora Brasileira Independente: produtora brasileira que atenda aos seguintes requisitos, cumulativamente:

a) ser constituída sob as leis brasileiras;

b) ter sede e administração no País;

c) $70 \%$ (setenta por cento) do capital total e votante devem ser de titularidade, direta ou indireta, de brasileiros natos ou naturalizados há mais de 10 (dez) anos;

d) a gestão das atividades da empresa e a responsabilidade editorial sobre os conteúdos produzidos devem ser privativas de brasileiros natos ou naturalizados há mais de 10 (dez) anos;

e) não ser controladora, controlada ou coligada a programadoras, empacotadoras, distribuidoras ou concessionárias de serviço de radiodifusão de sons e imagens; f) não estar vinculada a instrumento que, direta ou indiretamente, confira ou objetive conferir a sócios minoritários, quando estes forem programadoras, empacotadoras, distribuidoras ou concessionárias de serviços de radiodifusão de sons e imagens, direito de veto comercial ou qualquer tipo de interferência comercial sobre os conteúdos produzidos;

g) não manter vínculo de exclusividade que a impeça de produzir ou comercializar para terceiros os conteúdos audiovisuais por ela produzidos.

A Produtora, em especial, pode ser apontada como de maior risco na cadeia produtiva do cinema, pois é a última a ser remunerada, dado que tal remuneração decorre do lucro auferido após o recolhimento do distribuidor e do exibidor ${ }^{71}$. Desta maneira, a produtora encontra-se em uma situação

\footnotetext{
${ }^{70}$ Art. 50 Será constituído o Comitê Gestor dos recursos a que se refere o art. 20 desta Lei, com a finalidade de estabelecer as diretrizes e definir o plano anual de investimentos, acompanhar a implementação das ações e avaliar, anualmente, os resultados alcançados, tendo como secretariaexecutiva da categoria de programação específica a que se refere o art. 1o desta Lei a Ancine e como agente financeiro o Banco Nacional de Desenvolvimento Econômico e Social - BNDES ou outras instituições financeiras credenciadas pelo Comitê Gestor.

§ 1 o O Comitê Gestor será constituído por representantes do Ministério da Cultura, da Ancine, das instituições financeiras credenciadas e do setor audiovisual, observada a composição conforme disposto em regulamento.

${ }^{71}$ MICHEL, Rodrigo Cavalcante; AVELLAR, Ana Paula. A indústria cinematográfica brasileira: uma análise da dinâmica da produção e da concentração industrial . Revista de Economia da UFPR, p. 35-53, jan./abr. 2012. p.38
} 
extremamente delicada. Desta maneira, a Lei visa criar um cenário concorrencial isonômico para produtoras que não estejam associadas a grandes conglomerados empresariais gerando para a produção cinematográfica nacional, área estratégica para a difusão cultural, a pluralidade para sua participação.

Especificamente no mercado das cinebiografias isto estaria em assonância com a pluralidade de visões dos biografados, vez que haveria uma maior oportunidade de obtenção de recursos por parte dos produtores envolvidos e consequentemente meios variados para a realização da obra.

Todavia, outra recorrente exigência ${ }^{72}$ formulada pela autarquia nestas chamadas públicas vem a ser a exigência de apresentação de contrato de licença ou opção de direitos de uso de imagem, uso de nome ou outros referentes a personagens reais imprescindíveis para a realização da obra sob fundamento da exigência prescrita no artigo 20 do Código Civil de 2002. Ou seja, um determinado produtor de uma cinebiografia deverá obter a autorização ao uso de imagem do biografado no intuito de conseguir meios para financiar sua produção sob o risco de não conseguir sequer realizá-la.

Ocorre que, dada à visão patrimonial do direito à imagem amplamente difundida, muitas vezes o pequeno produtor não será capaz de pagar o valor exigido pelo biografado ou seus herdeiros para viabilização da sua obra. Diferente do mercado de sua congênere literária, que somente enfrentaria o absurdo dispositivo legal após sua produção, as limitações sofridas pelas cinebiografias são praticadas de maneira muito mais abrangente, e praticamente inviabilizaria o mercado das cinebiografias.

Desta forma, restaria ao dispor da boa-fé dos herdeiros e biografados oferecerem aos produtores independentes o direito para a licença do uso de imagem de modo gratuito ou a valores reduzidos.

Note-se, ainda, que sob a égide do artigo 20 do código civil de 2002 é cabível que os editais exijam licença de uso de imagem de personagens

\footnotetext{
${ }^{72}$ Desde sua criação, houve até o presente momento cinco editais para participação no PRODECINE referente à produção, um por ano. Ressalte-se que em 2011 não houve concurso. Destes, apenas os de 2008 e 2009 não contaram com a exigência de autorização de uso de imagem.
} 
reais. Uma vez que o FSA opera principalmente nas modalidades de investimento, financiamento e equalização de modo necessitar de retorno financeiro para alimentar o próprio fundo.

Assim sendo, caso a obra elaborada com verbas oriundas do FSA e, com base no referido instrumento legal, fosse retirada de circulação constituiria investimento sem retorno financeiro para o Fundo de maneira que o próprio restaria desfalcado em si. Porém, a simples possibilidade da ANCINE formular esta exigência no edital já indica que o próprio exercício do cerceamento excessivo à liberdade de expressão por ente privado categorizado pela existência do artigo 20 é, em alguma medida, exercido pela autarquia através de um viés econômico.

Neste sentido, além da obra não poder ser veiculada, intuito inicial do investimento, o dinheiro investido restaria desperdiçado em detrimento de outra produção passível de veiculação. É evidente, portanto, o esvaziamento que o art. 20 opera neste mecanismo de financiamento das cinebiografias independentes brasileiras que já enfrenta diversos empecilhos à produção.

\subsection{A Estrutura da Lei do Audiovisual: a exigência de autorização do uso de imagem e seu impacto nas Cinebiografias.}

A Lei do Audiovisual funciona a partir de mecanismos de incentivo baseados em renúncia fiscal em que pessoas físicas ou jurídicas realizam o aporte de capital num determinado projeto, sendo que o valor é abatido limitado a 3\% dos valores devidos- no imposto de renda devido. A Lei do Audiovisual funciona com dois mecanismos primordiais para a produção cinematográfica: o Art. $1^{\circ}$ e o Art. $3^{\circ}$. Cada um desses mecanismos tem diferentes fatos geradores, e pressupostos diferenciados de políticas públicas.

Através do art. $1^{\circ}$, pessoas físicas e jurídicas podem adquirir Certificados de Investimento Audiovisuais e abater os valores gastos nessa compra no Imposto de Renda, até o limite supracitado do imposto devido. 
Os certificados são negociados no mercado imobiliário após a aprovação da Secretaria para o Desenvolvimento do Audiovisual do Ministério da Cultura (MinC) ${ }^{73}$. Os projetos cinematográficos alvo dos investimentos deverão ser previamente aprovados pela ANCINE e, vale ressaltar, deverão ser obras independentes nos parâmetros já anteriormente explorados estabelecidos pela IN 104.

Apesar da Lei do Audiovisual estar em vigor desde 1993, foi apenas em 2002, com a introdução das modificações contidas na Medida Provisória ${ }^{0}$ 2.228-1/01, que o mecanismo gerado pelo Art. $3^{\circ}$ da Lei tornou-se efetivo uma vez que a criação da ANCINE pela MP permitiu sua operacionalização. Após essas modificações, tornou-se a principal fonte de financiamento das obras cinematográficas brasileiras de boas perspectivas de retorno comercial $^{74}$.

O Art. $3^{\circ}$ da Lei do Audiovisual incide sobre os impostos sobre os créditos e as remessas para o exterior em decorrência da exploração

\footnotetext{
${ }^{73}$ Art. 1 o Até o exercício fiscal de 2016, inclusive, os contribuintes poderão deduzir do imposto de renda devido as quantias referentes a investimentos feitos na produção de obras audiovisuais cinematográficas brasileiras de produção independente, mediante a aquisição de quotas representativas de direitos de comercialização sobre as referidas obras, desde que esses investimentos sejam realizados no mercado de capitais, em ativos previstos em lei e autorizados pela Comissão de Valores Mobiliários - CVM, e os projetos de produção tenham sido previamente aprovados pela Agência Nacional do Cinema - ANCINE. (Redação dada pela Lei no 12.375 , de 2010)

$\S 1^{\circ}$ A responsabilidade dos adquirentes é limitada à integralização das quotas subscritas.

$\S 2^{\circ}$ A dedução prevista neste artigo está limitada a três por cento do imposto devido pelas pessoas físicas e a um por cento do imposto devido pelas pessoas jurídicas. (Vide Lei 9.323, de 1996)

$\S 3^{\circ}$ Os valores aplicados nos investimentos de que trata o artigo anterior serão:

a) deduzidos do imposto devido no mês a que se referirem os investimentos, para as pessoas jurídicas que apuram o lucro mensal;

b) deduzidos do imposto devido na declaração de ajuste para:

1. as pessoas jurídicas que, tendo optado pelo recolhimento do imposto por estimativa, apuram o lucro real anual;

2. as pessoas físicas.

$\S 4^{\circ}$ A pessoa jurídica tributada com base no lucro real poderá, também, abater o total dos investimentos efetuados na forma deste artigo como despesa operacional.

$\S 5^{\circ}$ Os projetos específicos da área audiovisual, cinematográfica de exibição, distribuição e infra-estrutura técnica apresentados por empresa brasileira de capital nacional, poderão ser credenciados pelos Ministérios da Fazenda e da Cultura para fruição dos incentivos fiscais de que trata o caput deste artigo.

${ }^{74}$ IKEDA, Marcelo. O Art. $3^{\circ}$ da Lei do Audiovisual e as Políticas Públicas Para o Setor Audiovisual na retomada. - Disponível em $<$ http://www.direitosculturais.com.br/ojs/index.php/ojs/article/ viewFile/278/169> acessado em 01 mai. 2014.
} 
comercial de obras audiovisuais no território brasileiro (chamado CONDECINE - Remessa). Ao realizar a remessa (ou o crédito) para o exterior, os detentores dos direitos de comercialização da(s) obra(s) pagam imposto de renda sobre os valores.

Neste sentido, a opção pelo Art. $3^{\circ}$ da Lei do Audiovisual, implica no abatimento de $70 \%$ do valor do imposto de renda a ser pago para o investimento na coprodução de obras audiovisuais brasileiras de produção independente. Os 30\% restantes do imposto permanecem sendo recolhidos para a Receita Federal. Caso não seja utilizado o benefício fiscal deste artigo, a empresa recolhe o imposto de renda para a Receita Federal a sua totalidade. Nas palavras de Marcelo Ikeda:

\footnotetext{
"Este mecanismo constitui uma integração entre as produtoras independentes brasileiras e o oligopólio de distribuição global (as “majors”), buscou-se uma visão de promoção de obras eminentemente comerciais, através de um estímulo a associação entre dois elos complementares da cadeia produtiva do audiovisual: a produção e a distribuição ${ }^{75}$."
}

Todavia, o artigo $3^{\circ}$ da Lei do Audiovisual somente é aplicável a projetos previamente aprovados pela autarquia. Neste sentido, para a sua aprovação os projetos devem cumprir uma série de pré-requisitos expressos na Instrução Normativa 22 da Ancine, alterada pela IN 99. Um destes prérequisitos dispõe o seguinte:

Art. $8^{\circ}$ - Os projetos de obras audiovisuais brasileiras deverão constituir-se dos seguintes documentos a serem entregues em uma única via, conforme a seguir especificado

f) No caso de obra audiovisual baseada em personalidade, a autorização de uso de imagem da personalidade, quando couber;

Ou seja, todos os mecanismos de financiamento das cinebiografias encontram-se reféns do impedimento prescrito no artigo 20 do código civil. É válido destacar que isto causa cenários verdadeiras distorções à

\footnotetext{
${ }^{75}$ IKEDA, Marcelo. O Art. $3^{\circ}$ da Lei do Audiovisual e as Políticas Públicas Para o Setor Audiovisual na retomada. - Disponível em
} 
construção de uma memória coletiva do Brasil enquanto nação em si. Neste sentido, não seria possível elaborar-se uma cinebiografia sobre personagens de amplo destaque histórico há muito mortos tais como D. Pedro II ou Getúlio Vargas sem a regular autorização de uso de imagem destes herdeiros.

E ainda, personagens históricos em função nem sempre tem herdeiros de fácil localização, dada às dificuldades formadas por ausência de registros adequados ou ainda, falta de informações a respeito dos descendentes em função do distanciamento impresso pelo tempo. Neste sentido, o que deve ser feito quando estes herdeiros não forem localizados? A própria produção restará impossibilitada?

Com o intuito de obter a aprovação do documentário "Louco, Louco e Louco”, biografia do arquiteto Antonio Giuseppe Landi, arquiteto italiano responsável pela realização de importantes construções históricas na região Norte do país, especialmente no Estado do Pará, foi protocolado junto à ANCINE o projeto deste filme na forma do processo administrativo 01580.014918/2011-86. Todavia o pedido não fora instruído com a licença de uso de imagem pelos seus herdeiros em função de desconhecimento da existência de qualquer herdeiro do arquiteto.

Para que o referido projeto fosse aprovado, a autarquia exigiu que as referidas autorizações fossem, de toda forma, apresentadas ao caso. A fim de cumprir com a exigência, foi contatado o Instituto Italiano di Cultura do Rio de Janeiro, ocasião em que o Adido Cultural da Itália no Brasil, atendeu a solicitação, informando que seria necessário averiguar as informações com a Secretaria de Cultura de Bologna, região em que nasceu Giuseppe Landi.

A Secretaria de Cultura de Bologna, capital da região de EmiliaRomagna, realizou um importante projeto audiovisual sobre o Sr. Landi e desenvolveu um site em parceria com a Universidade Federal do Pará

<http://www.direitosculturais.com.br/ojs/index.php/ojs/article/ viewFile/278/169> acessado em 01 mai. 2014. 
(foumlandi.ufpa.br), que reunia obras, biografia e informações bibliográficas do arquiteto. Note-se aqui que já havia biografias não autorizadas divulgadas pela própria UFPA.

Todavia nem a Secretaria de Cultura da região natal do arquiteto, nem a Universidade Federal do Pará possuíam quaisquer informações sobre a existência descendentes de Giuseppe Landi.

Em resumo, a produtora recebeu informações de que o arquiteto morrera há mais de 300 anos e não havia qualquer notícia sobre a existência de herdeiros legítimos, não havia qualquer registro do rosto do arquiteto de maneira que somente se trabalhava com o conceito de imagem-atributo e, que os únicos direitos que poderiam ser liberados seriam aqueles relacionados aos desenhos, quadros, imagens em geral, que pertencem a instituições específicas, constantes no site sobre o arquiteto e que podem ser acessadas quando necessário.

Ressalte-se, portanto, que nem o documentário realizado com o apoio da Secretaria de Cultura de Bologna nem o forumlandi.ufpa.br contavam com documento de liberação de direito de imagem de Giuseppe Landi, posto que não exista possibilidade concreta de obtenção de tal documento. Neste sentido, se nem o próprio Estado Italiano foi capaz de localizar estes herdeiros a obtenção de uma licença que atendesse os ditames do artigo 20 do Código Civil era impraticável.

A produtora alegou ainda, dada à impossibilidade fática comprovada de obtenção do documento de liberação de direito de imagem, a aplicação análoga do artigo 45 da Lei 9.610/98 ${ }^{76}$, onde reputam-se em domínio público os direitos patrimoniais das obras de autores falecidos que não tenham deixado sucessores ou de autor desconhecido. Ainda que os regimes jurídicos dos institutos sejam totalmente distintos (Direito de Autor

\footnotetext{
${ }^{76}$ Art. 45. Além das obras em relação às quais decorreu o prazo de proteção aos direitos patrimoniais, pertencem ao domínio público:

I - as de autores falecidos que não tenham deixado sucessores;

II - as de autor desconhecido, ressalvada a proteção legal aos conhecimentos étnicos e tradicionais.
} 
x Direito de Imagem), o arcabouço legal que regula a produção audiovisual aproximaria ambos no caso concreto.

A autarquia decidiu por fim que, em função de todos os esforços razoáveis para localização dos herdeiros terem sido envidados sem sucesso, não haveria razão para manter a exigência desta autorização de uso de imagem. Todavia, o que teria acontecido sem a intervenção da Secretaria de Cultura de Bologna? E na hipótese em que não resta provado a impossibilidade de localizar os herdeiros do biografado? Há que ressaltar que investigações desta natureza nem sempre serão elaboradas de maneira barata, excluindo as produtoras menos capitalizadas.

Apenas a título ilustrativo, a negativa de seguimento ao andamento do projeto “Louco, Louco e ainda Louco", sobre a vida e a história de Giuseppe Landi, pelo impedimento prescrito pelo artigo 20 do Código Civil, seria o mesmo que impossibilitar a realização de uma obra documental sobre qualquer grande personalidade tais como César, Pedro Álvares Cabral, Sócrates ou Cleópatra. 


\section{Conclusão}

A história não é somente composta por grandes feitos e atos heroicos, mas também por suas tragédias e desgraças. O que seria de uma cinebiografia sobre Getúlio Vargas sem menção ao seu suicídio? Ou mesmo de uma sobre Adolf Hitler sem mencionar o massacre judeu?

A cada vez que se revisita a história em busca do passado deve-se assumir uma postura crítica e questionadora em relação ao seu objeto de estudo pois, de outro modo, perde sua razão de ser. Neste sentido, as ditas biografias não autorizadas cumprem seu papel de questionar personalidades ao evitar uma visão "chapa branca” a respeito do passado.

Não se trata de permitir a invasão de privacidade do biografado ou mesmo a divulgação de informações inverídicas a seu respeito. Por outro lado, também não se trata de permitir que se construa uma imagem unilateral a respeito de qualquer personalidade que, como qualquer um, possui diversas características plurais.

Todavia, a natureza jurídica do exercício do direito de resposta proporcional à violação é suficiente para sanar os abusos de direito perpetrados por uma biografia. $\mathrm{O}$ uso deste direito, extremamente mal aproveitado pelo Judiciário Nacional, pode ser considerado elemento fundamental ao com exercício da liberdade de expressão de maneira saudável e democrática.

A mera aprovação pela Câmara dos Deputados da nova redação dada ao artigo 20 do CC. trazida pelo projeto de Lei 393/2011 deve ser encarada com desconfiança. A emenda apresentada pelo deputado Ronaldo Caiado permitiria a retirada de circulação de trechos ofensivos à pessoa humana mediante rito sumário da Lei dos Juizados Especiais também permite o esvaziamento, sem qualquer cuidado com a informação tolhida, da discussão à cerca do biografado.

A nova redação dada ao artigo 20 do CC. não tem o condão explícito de modificar a posição da ANCINE frente à exigência da autorização de uso 
de imagem. A justificativa da autarquia para tanto reside na possibilidade de que a retirada de circulação da obra gere dano direto ou indireto ao erário, seja por desperdício de verba fiscal incentivada, seja por não receber o retorno aguardado do Fundo Setorial Audiovisual.

A exigência de autorização prévia do uso de imagem de personalidades retratadas no cinema pela ANCINE, embasada pela limitação do artigo 20 do Código Civil, consiste em um excessivo ônus aos produtores brasileiros independentes. Consequentemente, a própria possibilidade de produção de uma cinebiografia por uma produtora independente é bastante complicada, vez que o mercado cinematográfico depende totalmente das políticas públicas de incentivo a produção.

Neste sentido, em um país com um grande índice de analfabetos ${ }^{77}$, a cinebiografia que poderia ser útil à difusão da memória, perde a oportunidade dinâmica de contar sua história ao seu povo tendo em vista que é vista gênero refutado por aqueles que deveriam apoiá-la.

Ocorre ainda, em decorrência da exigência de autorização de uso de imagem, um monopólio da produção de cinebiografias por parte das produtoras ligadas a grandes conglomerados midiáticos. Ou seja, não assegura o pluralismo de visões constitucionalmente previsto vez que apenas assegura mais espaço para veículos que já possuem amplo meio de divulgação de suas produções e escolhas sócio-políticas.

A viabilidade de uma cinebiografia depende apenas da postura que o judiciário e ANCINE assumirão frente à legislação vigente.

\footnotetext{
${ }^{77}$ De acordo com dados do 11을 Relatório de Monitoramento Global de Educação para Todos organizado pela Organização das Nações Unidas para a Educação, a Ciência e a Cultura (Unesco) cerca de 8,6\% doa brasileiros com mais de 15 anos são analfabetos.
} 


\section{Bibliografia}

AFFORNALI, Maria Cecília Naréssi Munhos, Direito A Própria Imagem. 1ªed.Curitiba: Juruá, 2012. 141 p.

ARAÚJO, Luiz Alberto David. Proteção Constitucional Do Direito A Própria Imagem. 2aed. Belo Horizonte: Verbatim, 2013. 233 p.

ASSENJO, Porfírio Barroso; TALAVERA, María del Mar López, La Libertad de Expresión y sus Limitaciones Constitucionales. Madrid: Fragua, 1998. 267 p.

BITTAR, Carlos Alberto. Os direitos da personalidade. $2^{\mathrm{a}}$. ed. Rio de Janeiro: Forense Universitária, 1995.

CARNEIRO, Luiz Felipe. - O terreno minado das biografias não autorizadas no Brasil. In: Schreiber, Anderson. Direito e Mídia. $1^{\mathrm{a}}$ ed. Rio de Janeiro: Renovar, 1999. p.118-131

CARVALHO, Luis Gustavo Grandinetti Castanho de, Direito de Informação e Liberdade de Expressão. $1^{\mathrm{a}} \mathrm{ed}$. Rio de Janeiro: Renovar, 1999. $338 \mathrm{p}$.

DELFINA, Cristiana, Generalizando a vida real. $O$ que retratam as cinebiografias? Disponível em $<$ http://www.comciencia.br/comciencia/handler.php?section=8\&edicao=96 \&id=1177 a> Acesso 22 mai. 2014

DONEDA, Danilo. Os Direitos da Personalidade no Código Civil. In:TEPEDINO, Gustavo (Org.) A Parte Geral do Novo Código Civil. $3^{\mathrm{a}}$ ed. Rio de Janeiro: Renovar, 2007 p. 35-60

DOSSE, François - O Desafio Biográfico: Escrever uma vida. $1^{\mathrm{a}}$ ed. São Paulo: EdUSP, 2009. 440 p.

FARIAS, Edilsom - Liberdade de Expressão e Comunicação: Teoria e Proteção Constitucional. $1^{\text {a }}$ ed. São Paulo: Revista dos Tribunais, 2004. 204 p.

IKEDA, Marcelo. O Art. $3^{\circ}$ da Lei do Audiovisual e as Políticas Públicas Para o Setor Audiovisual na retomada. - Disponível em $<$ http://www.direitosculturais.com.br/ojs/index.php/ojs/article/ viewFile/278/169> acessado em 01 mai. 2014. 
MICHEL, Rodrigo Cavalcante; AVELLAR, Ana Paula. A indústria cinematográfica brasileira: uma análise da dinâmica da produção e da concentração industrial. Revista de Economia da UFPR, p.36-53jan./abr. 2012.

MORAES, Alexandre; Direito Constitucional, 24 ${ }^{\mathrm{a}}$ ed. São Paulo: Atlas, 2009

PEREIRA, Caio Mario da Silva. Instituições de Direito Civil. vol.1. 22a ed. Rio de Janeiro: Forense, 2008.

TEPEDINO, Gustavo. A tutela da personalidade no ordenamento civilconstitucional brasileiro. In: TEPEDINO, Gustavo. Temas De Direito Civil. $3^{\mathrm{a}}$ ed. Rio de Janeiro: Renovar, 2004. p. 23-58

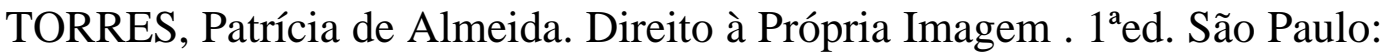
LTR, 1998. 136 p.

TJRJ, Apelação Cível 39.193, Rel. Wellington Moreira Pimentel, 17 dez. 1985.

STJ, Recurso Especial 299832, Rel. Ricardo Villas Bôas Cueva, 21 fev. 2013 